Article

\title{
Employment, Utilization, and Development of Airborne Laser Scanning in Fenno-Scandinavian Archaeology-A Review
}

\author{
Ole Risbøl ${ }^{1, *}$, Daniel Langhammer ${ }^{2}$, Esben Schlosser Mauritsen ${ }^{3}$ and Oula Seitsonen ${ }^{4,5}$ (D) \\ 1 Department of Archaeology and Cultural History, NTNU University Museum, 7012 Trondheim, Norway \\ 2 The County Administrative Board of Gotland, 62185 Visby, Sweden; daniel.langhammer@lansstyrelsen.se \\ 3 ARKVEST, Ringkøbing-Skjern Museum, 6900 Skjern, Denmark; esm@arkvest.dk \\ 4 Archaeology, University of Oulu, 90570 Oulu, Finland; oula.seitsonen@gmail.com \\ 5 Archaeology, University of Helsinki, 00014 Helsinki, Finland \\ * Correspondence: ole.risbol@ntnu.no
}

Received: 2 March 2020; Accepted: 24 April 2020; Published: 30 April 2020

check for updates

\begin{abstract}
This paper gives a presentation of how airborne laser scanning (ALS) has been adopted in archaeology in the North over the period 2005-2019. Almost two decades have passed since ALS first emerged as a potential tool to add to the archaeologist's toolbox. Soon after, it attracted the attention of researchers within archaeological communities engaged with remote sensing in the Fenno-Scandinavian region. The first archaeological ALS projects gave immediate good results and led to further use, research, and development through new projects that followed various tracks. The bulk of the research and development focused on studying how well-suited ALS is for identifying, mapping, and documenting archaeological features in outfield land, mainly in forested areas. The poor situation in terms of lack of information on archaeological records in outfield areas has been challenging for research and especially for cultural heritage management for a long period of time. Consequently, an obvious direction was to study how ALS-based mapping of cultural features in forests could help to improve the survey situation. This led to various statistical analyses and studies covering research questions related to for instance effects on detection success of laser pulse density, and the size and shape of the targeted features. Substantial research has also been devoted to the development and assessment of semi-automatic detection of archaeological features based on the use of algorithms. This has been studied as an alternative approach to human desk-based visual analyses and interpretations of ALS data. This approach has considerable potential for detecting sites over large regions such as the vast roadless and unbuilt wilderness regions of northern Fennoscandia, and has proven highly successful. In addition, the current review presents how ALS has been employed for monitoring purposes and for landscape studies, including how it can influence landscape understanding. Finally, the most recent advance within ALS research and development has been discussed: testing of the use of drones for data acquisition. In conclusion, aspects related to the utilization of ALS in archaeological research and cultural heritage management are summarized and discussed, together with thoughts about future perspectives.
\end{abstract}

Keywords: review; remote sensing; airborne LiDAR; mapping; archaeology; Fenno-Scandinavia

\section{Introduction}

Airborne laser scanning (ALS) is a remote sensing technique where short pulses of near-infrared light are emitted towards the ground from a sensor mounted on an aircraft. The pulses are distributed to both sides of the flight direction by a mirror tilting back and forth at an angle of typically $<20^{\circ}$ (scan angle). This causes the ALS data to be collected in a corridor under the aircraft that is normally 
between 100 and $1000 \mathrm{~m}$ wide. The light pulses are reflected back to the sensor from what is hit on the ground, whether it be vegetation, buildings, or terrain, among other options. The position of each reflection can then be calculated in three dimensions (3D) using knowledge of the plane's position and orientation in space as well as the scan angle and the time it takes from the pulse to leave the sensor until the returns are recorded in the sensor. These data consist of millions of points stored in a point cloud and can be used to create digital surface models (DSMs). In such models one can choose to filter out the pulses reflected from vegetation or buildings and be left with a detailed terrain model of the bare ground. Such terrain models devoid of vegetation are very suitable for analyzing, interpreting, and visualizing conditions on the ground in 3D from all angles and aspects ranging from a frog's to a bird's perspective.

The history of the use of (ALS) in archaeology is brief: If one were to define a year zero, that year would be the year 2000, when the first ALS images for archaeological purposes were presented in September at the Aerial Archaeological Research Group meeting in Aberdeen, Scotland [1,2] The dissemination of results from the utilization of ALS in archaeology immediately gained interest among archaeologists engaged in remote sensing, who began to explore the potential of this new laser-based technology. Initially ALS data collected for other purposes (mainly flood analysis) were utilized, but soon archaeologists started to commission their own flight missions to areas of specific archaeological interest [3-6]. Since then, the use of ALS has seen exponential growth in archaeology, becoming commonplace across the world. This review covers the countries of Denmark, Norway, Sweden, and Finland - an area also known as Fenno-Scandinavia or Fennoscandia. The definition of Fenno-Scandinavia can vary slightly, but in this context, the term is used to refer to the area covering Finland plus the three Scandinavian countries Denmark, Norway, and Sweden (see https://en.wikipedia.org/wiki/Fennoscandia with references) (Figure 1).

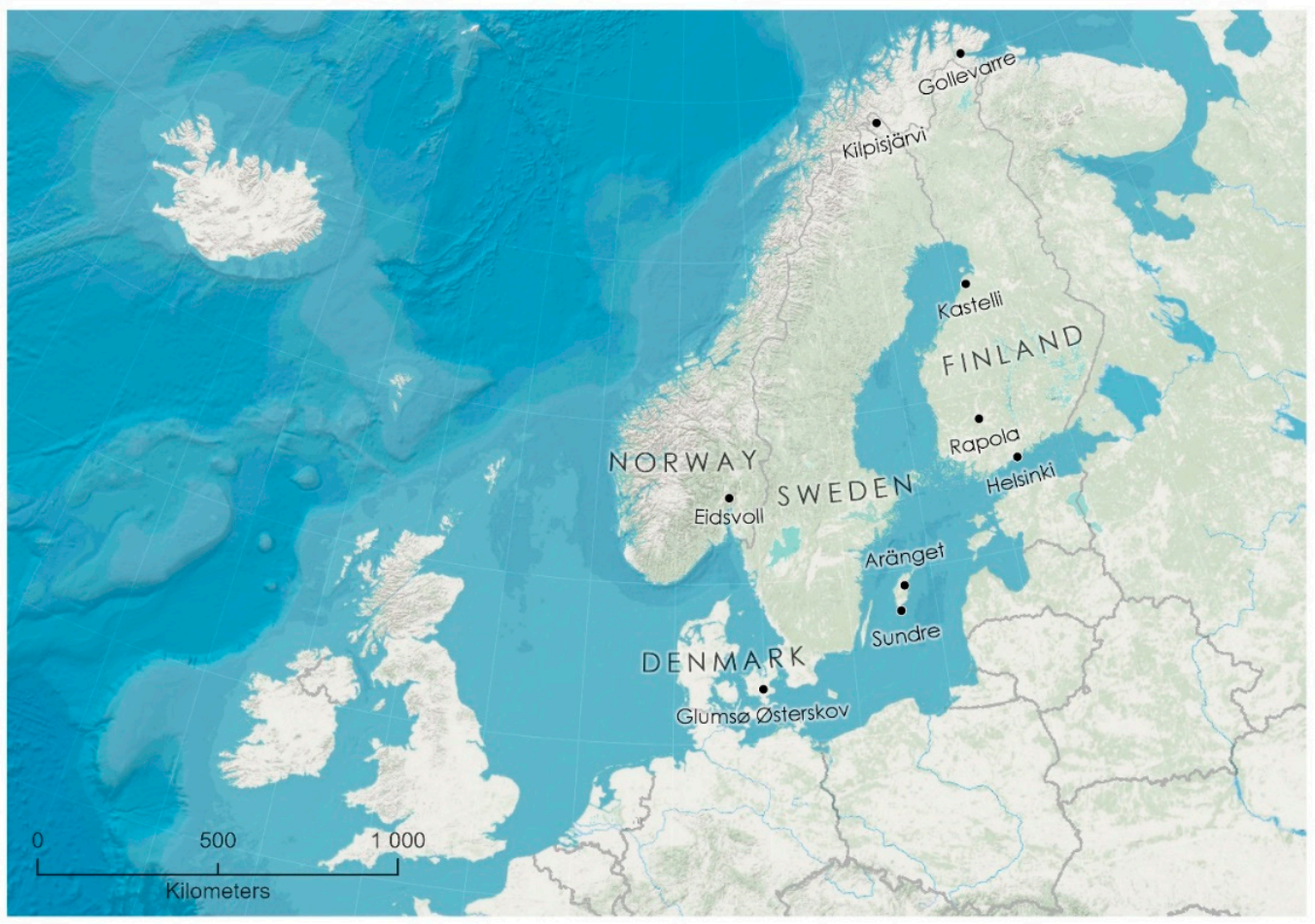

Figure 1. The Fenno-Scandinavian countries. The geographical positions of the sites presented in this article are indicated on this map. This is a matter of Eidsvoll: Figure 3, Glumsø Østerskov: Figure 4; Aränget: Figures 5 and 6; Kastelli, Kilpisjärvi, and Helsinki: Figure 7; Sundre: Figure 8 and Figure 9; Gollevarre: Figure 10; and Rapola; Figure 11. Illustration: Magnar Mojaren Gran, NTNU University Museum. 
In the Fenno-Scandinavian region, the first archaeological ALS campaign was conducted in 2005 in a forested area measuring $10 \mathrm{~km}^{2}$ in Hedmark, south-eastern Norway [6], with the good results it yielded leading to several ALS projects across Norway in the following years. The first published study using ALS data for archaeological purposes in Denmark dates back to 2010 [7], and involved a presentation of mappings and studies from a project that was conducted over the course of several years with respect to Celtic Iron Age field systems on the islands of Sjælland, Møn, and Lolland-Falster. A national 0.45-point $/ \mathrm{m}^{2}$ data set was incorporated into the project at a late stage as a source of comparison to already known field systems, but not in the search for new ones [8,9]. The project was based on decades of fieldwalking in forested areas by the late archaeologist Viggo Nielsen.

The pioneering work conducted by Norwegian archaeologists in combination with the growing application of ALS in other fields shaped early developments in Swedish archaeology. In 2006, the first tentative steps towards exploring the use of ALS as a tool for cultural heritage management were taken by the County Administrative Board of Dalarna in collaboration with the Swedish Forest Agency. The project included ALS data regarding 36,000 hectares in the municipality of Leksand in the county of Dalarna [10]. The core of the study focused on problems pertaining to the quality of the specific data set used (as well as the terrain model representations derived from it) in relation to the types of sites visible in the data, plus data anomalies that might result in misinterpretations. In Finland, the archaeological application of ALS started in 2009 as open-access data became available from the Finnish National Land Survey (FNLS). The first archaeological projects were initiated by researchers from the University of Helsinki and the National Heritage Agency (NHA), the results of which were published in the following years [11,12]. Owing to fact that point clouds and ALS-generated digital elevation models (DEMs) were available as open-access data in Finland from the beginning, no specifically archaeological scanning campaigns were undertaken in the country until 2018 when the first drone-based ALS was conducted.

After 15 years of ALS in Fenno-Scandinavian archaeology, we deem it timely to take stock and evaluate our role in the overall development of ALS archaeology, stating our current position and indicating some probable future perspectives. Thus, the objective of this article is to collate the use of archaeological ALS in Fenno-Scandinavia in order to illuminate its contribution to ALS's employment in archaeology. It is our aim to share Fenno-Scandinavian ALS with a broader audience by providing a synthesized overview of the current state of knowledge. This overview will also include ALS research and development material that has been published in one of the Scandinavian languages or in Finnish, and consequently has only been available for a limited audience. We anticipate that this review will advance knowledge in general and perhaps even inspire archaeologists or students without experience in remote sensing, and thereby potentially broaden the remote sensing community. The reasoning behind this review paper is further to identify existing gaps and point out some future research directions. Thus, the aim of the review is:

- To promote and convey how ALS has been used for archaeological purposes in the Fenno-Scandinavian region

- To put this into an international context

- To identify knowledge gaps

- To point out some future perspectives

The introduction of ALS in archaeology has provided an unprecedented possibility to work with extremely detailed three-dimensional (3D) digital terrain models (DTMs) that may have considerable value in archaeology, such as by identifying various monuments and features that are visible above ground but are hence far unrecognized. If one were to point to a single factor behind the successful employment of ALS in archaeology, it would be its unequalled capability to penetrate vegetation. This quality has rendered it possible to make remarkably detailed mappings of entire landscapes from above, including parts of the landscape that are covered by vegetation. Our knowledge about past human impacts on forested areas is inadequate compared to that of agricultural landscapes and in 
many countries these areas have received little attention from archaeologists, despite the fact that cultural features and remains are often better preserved in forests than in areas subjected to agricultural activities $[13,14]$. Thus, the main impetus for archaeologists to employ ALS is the potential it offers in terms of enhanced knowledge about archaeology in forested areas [15-18]. This essentially implies the improvement of cultural heritage databases to contain all parts of the environment in a more balanced manner.

This assertion about a biased dichotomy between forested outfield areas and agricultural land in terms of past human impacts does not imply that the survey situation in arable land is clear or adequate. Rather, the point is that the likelihood that visible, elevated, non-buried archaeological features and monuments are listed in cultural heritage databases is much higher if they are situated in agricultural landscapes than in outfield areas. This is a result of skewed survey intensity (see also below). In Sweden, specialized surveys within Skog \& historia (Forest \& History), a national project based on job creation measures, have helped to reduce this bias to some extent, with the project contributing to an additional 200,000 sites in forest areas [19].

Another major advantage of ALS is the fact that it provides an overview of the landscape and the sites located within it from a bird's-eye perspective, which is something that is difficult and time-consuming to obtain with a worm's-eye view from the ground. This is valid for general outfield use but is especially relevant when it comes to extensive sites visible in the data, such as Celtic fields, an example discussed in further detail below.

With this as a background, the state of the art concerning the use of ALSin Fenno-Scandinavian archaeology will be established in the following section through a review of published literature from the Fenno-Scandinavian region. The review is structured in such a way that results from Norway are discussed first, followed by achievements from Denmark, Sweden, and Finland. Where a country is omitted it is because no development has occurred in that country within the specific ALS topic addressed in the concerned section. The review section will be followed by a summary and discussion (additionally comprising future perspectives), before some concluding remarks to finish.

\section{Literature Review}

\subsection{Method}

The state of the art in this review was not established through a systematic search of electronic literature databases; instead, the overview was developed thanks to the authors' intimate knowledge of ALS use and of scholars involved in this field in their respective countries. Each author has been engaged in remote sensing and ALS practice for many years in their respective country. This fact, in combination with the modest number of archaeologists involved in ALS research and development in the Fenno-Scandinavian countries, has ensured that the state-of-the art review includes all essential published contributions to Fenno-Scandinavian ALS employment in archaeology. Thus, this review can be defined as a meta-analysis rather than an analysis based on systematic database searches.

Included in this review are published works of any kind, such as papers, book chapters, and reports. No distinction has been made regarding languages and references: Norwegian, Danish, Swedish, and Finnish as well as English publications have been included. The time span from the earliest publication to the latest is 2006 to 2019. Further, there are a few references to Fenno-Scandinavian publications currently in press.

\subsection{ALS Data Availability}

There is reason to believe that the availability of ALS data to the archaeological community is of importance with regard to its adoption in this discipline. This also pertains to the quality (i.e., the resolution) of data. These circumstances vary among the Fenno-Scandinavian countries and a short account of availability and quality is given here (Table 1). 
Table 1. Overview of national airborne laser scanning (ALS) coverage in Norway, Denmark, Sweden, and Finland. The table also shows when the data were acquired as well as their resolution and availability.

\begin{tabular}{ccccc}
\hline Country & Acquisition Year & Points $/ \mathbf{m}^{\mathbf{2}}$ & Grid Size (m) & Open Access \\
\hline Norway & $2011-2013$ & 0.01 & 10 & Yes \\
Norway & $2016-2022$ & 2 & 1 & Yes \\
Denmark & $2005-2007$ & 0.45 & 1.6 & Yes \\
Denmark & $2014-2015$ & $4-5$ & 0.4 & Yes \\
Sweden & $2009-2019$ & $0.5-1$ & 1 & No \\
Sweden & $2018-$ present & $1-2$ & - & Yes \\
\hline Finland & $2008-2019$ & 0.5 & 2 & Yes \\
\hline
\end{tabular}

In Norway, a coarse national height model with a resolution of $10 \times 10 \mathrm{~m}$ (equaling 1 point $/ 100 \mathrm{~m}^{2}$ ) has been available for many years, but a detailed national elevation model with 2 points $/ \mathrm{m}^{2}$ is currently being prepared. National coverage scanning started in 2016 and is expected to be completed in 2022 [20]. The data are being made freely available on a continuous basis as they are collected [21]. Aside from mountainous areas mapped by photogrammetry (in total measuring approximately $39,000 \mathrm{~km}^{2}$ ), the national elevation model is based on ALS (covering in total approximately $286,000 \mathrm{~km}^{2}$ ). Prior to the launch of the national coverage campaign, many small, medium-sized, and quite large ALS projects were carried out across the country, mainly by local and regional authorities as well as by various industries and administrations. Including a pilot project related to the national coverage, approximately $57,000 \mathrm{~km}^{2}$ of Norway were scanned using ALS from 2005 through to 2015 [22]. The greater part of these data was made available for the public administration and academia.

In Denmark, two national ALS surveys of the country were performed. The first was commissioned by the state in 2005 , with a $0.45-$ point $/ \mathrm{m}^{2}$ resolution stored in a $1.6-\mathrm{m}$ grid [23]. These data were made available to all archaeological museums in 2009 and from 2010 to the general public, along with all other governmental geodata [24]. In 2014, only nine years after the first scan, a new national ALS survey was conducted, this time with a resolution of $4-5$ points $/ \mathrm{m}^{2}$ [25]. The hillshades are easily accessible on web geographic information system (GIS) platforms such as the one provided by the Danish Geodata Agency [26].

In Sweden, a national ALS-generated height model has been in production since 2009, with the major parts of the country scanned by 2013. The work has continued with complementary laser scanning of areas such as the mountainous inlands [27]. During this period, different products have been released based on the point clouds. These include raster images at a 2-m resolution produced from about 2010. The release of a web map service (WMS) for hillshades and slopes produced at a 1-m resolution from about 2014 and a web coverage server (WCS) from 2015 [28,29] made ALS accessible to archaeologists with no or limited experience in GIS and LAS data. Public web-based map applications are easy to access, for example the national database for archaeological sites Fornsök [30] or web maps provided by the National Forest Agency that allow the user to set sun parameters. In this short period of time, ALS availability has affected archaeological surveys, landscape analyses, and heritage management. Since 2018, additional scanning at a higher resolution has focused on forest areas, producing a point cloud of 1-2 points $/ \mathrm{m}^{2}$ [31]. In contrast to previous products associated with costs, unless the organization is part of a national geodata agreement, these new data are licensed under CC0, a Creative Commons tool for releasing material into the public domain. It constitutes an interesting development at the National Mapping Agency, offering some hope for additional open access ALS products in the future.

In Finland, the FNLS started producing ALS point cloud data in 2008 and made them available for universities and other scientific institutions in 2009. Since 2012, all such material has been available with open access through these organizations' websites [32]. The FNLS ALS data are unfortunately rather coarse, with a mean density of 0.5 points $/ \mathrm{m}^{2}$, limiting their usability in archaeology. The FNLS is currently producing an open-access DEM with 2-m resolution from the ALS data. This is based 
on an ongoing scanning campaign covering the whole country, which should be completed in 2020 . Subsequently, the FNLS will launch new high-resolution ALS mapping.

To recapitulate, there is reason to believe that ALS availability across Fenno-Scandinavia is contributing greatly to archaeologists' existing toolkits by offering detailed spatial data that simply were not available or affordable before.

\subsection{Archaeologies, Topographies, and Landscapes}

The Fenno-Scandinavian countries are quite diverse in terms of size, topography, and land cover. Most relevant in this regard is the uneven distribution of arable land versus forested areas (Figure 2). This is important because it is reflected in how and where ALS is utilized as a tool in archaeology in the different countries, for example, in built up areas, areas of bare rock, glaciers, heathlands, bogs etc.

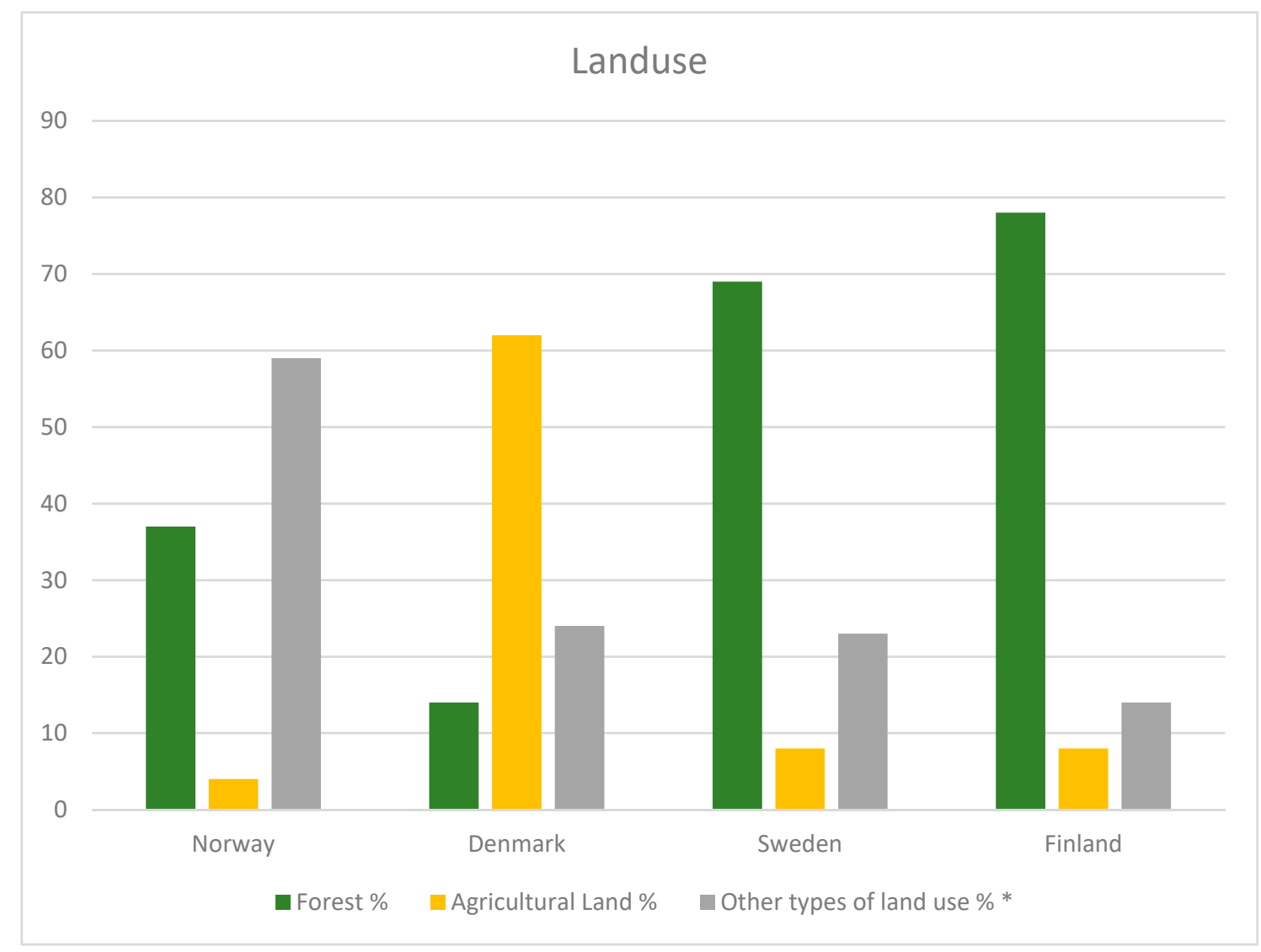

Figure 2. A bar diagram showing the distribution of forest, agricultural land, and other types of land use.

In addition to inland waters, permanent snow, and glaciers, the bulk of the land cover in Norway is made up of forests, open firm ground, and areas with bare rock, gravel, and block fields. Altogether, these outfield categories represent more than $95 \%$ of the land cover, of which a little more than $37 \%$ is forested land, only $4 \%$ is agricultural land, and the rest comprises built-up areas [33]. Both agricultural and outfield land have been utilized by humans for various purposes throughout history. Today, a large proportion of the visible archaeological monuments and features are found in outfield areas, while monuments and features situated in farming areas have to a greater extent been plough-levelled. In Norway all monuments, features, and sites are automatically protected by law if they predate the Reformation, which took place in 1537. This applies to all kinds of human traces irrespective of their preservation condition. For Sami cultural heritage, legal protection is valid for 
all monuments, features, and sites predating 1917 (the year of the first Sami national meeting held in Trondheim in February 1917).

Unlike the other Fenno-Scandinavian countries, Denmark is almost completely cultivated. Hence, untouched archaeological features can only be found in a fraction of the country. Historically, large parts of Denmark were covered by moorland, but since the mid-20th century only $2 \%$ of the country remains as heathland. Forests and plantations today constitute 14\%; in 1950, the percentage was only $8 \%$, of which just $4 \%$ comprised old forested areas prior to 1805 [34]. Much of the "new" forest (4\%) was planted on former heathland between 1805 and 1960 [35], potentially on previously untouched landscapes [36]. A rough estimate could be that only $4-5 \%$ of Denmark has the potential to host archaeological features not been subjected to modern cultivation. However, a large number of ploughed earthworks exist in the cultivated landscape: in particular, plough-levelled Neolithic and early Bronze Age mounds are visible in considerable numbers. A query in the current Fund \&Fortidsminder database shows that more than 90,000 burial mounds are known of in Denmark [37], but the actual number is probably much higher. Many of the plough-levelled mounds are easily detectable in the ALS studies and thousands are waiting to be found. Also worth mentioning are the 33,000 scheduled monuments in Denmark [38], mostly comprising burial mounds. According to Danish law, all visible monuments are protected, and they can all be found in the ALS surveys, or at least they should be, as some scheduled monuments have been destroyed through criminal acts. In these cases, digital surface models can provide important documentation for both legal and scientific purposes.

Land use data in Sweden vary slightly according to the statistics in question, but according to the data presented by Statistics Sweden, forest land constitutes about $69 \%$ of land use, while agricultural land use is estimated to represent about $8 \%$ [39]. Productive forests represent around $50 \%$, and by no surprise ALS was used at an early stage within forestry planning, as was also true of other remote sensing techniques beforehand. In Swedish legislation, archaeological sites and monuments dating before 1850 are considered protected sites if they were erected using old techniques and are now permanently abandoned. Those sites that are not protected by the Cultural Heritage Act still need to be respected by forestry, due to further regulations through the Forestry Act. Well-integrated heritage management is required in order to ensure that forestry proves sustainable, yet a high percentage of archaeological features in productive forest land has been lost or exhibits traces of damage. This has been proved through studies from Norway and Sweden [40]. Finland is the most-forested (over $70 \%$ ) of the Fenno-Scandinavian countries and, like in Sweden, the use of ALS and other remote sensing approaches originated from the needs of the forestry industry. Water bodies and wetlands cover about $15 \%$ of the country, while other natural land cover types (such as alpine tundra in the north) represent approximately $3 \%$; together with forests these types amount to over $90 \%$ of the country [41]. Agricultural land use represents less than $8 \%$ and built-up areas about $1 \%$ of Finland. Cultural heritage sites in the country are protected by the Antiquities Act, which imposes no temporal limits on the protected sites. For instance, (Russian) First World War fortifications and Finnish Civil War (1918) structures are protected as "Ancient Monuments" by the NHA. The Finnish National Board of Forestry (FNBF) has made a landmark decision based on the rights of the landowner, extending protected heritage status to cover all Second World War remains and forestry structures until the 1960s on the lands they control [42]. These sites have, from the mid-20th century, been recognized by the NHA as "other cultural heritage sites" but are not automatically protected [43]. In the thinly populated forest and felling regions of northern and eastern Finland especially, vast stretches of land are archaeologically virtually untouched. ALS-based remote sensing has already demonstrated its value in directing fieldwork in these often roadless and densely forested areas. 


\subsection{Identifying, Mapping, and Documenting Cultural Features}

From the very start, ALS was regarded as an appropriate technique with excellent potential to improve overviews and databases holding information about cultural monuments and remains [6]. High-quality registers and records with good geographical coverage are a prerequisite for effective cultural heritage management procedures. However, the biased content of cultural heritage databases, in which the coverage of outfield and forested land is usually flawed compared to the agricultural landscape, hampers this goal $[44,45]$. As previously mentioned, this issue is related to the elevated archaeology visible above the ground. This skewed situation also represents a challenge that applies to research, where especially landscape archaeology studies are vitiated by deficient information about past human presence and practices in all parts of the landscape. Based on the results of extensive archaeological survey campaigns and excavation projects over the years, we know that the impacts of human actions on outfield areas are comprehensive and to a considerable extent still visible on the landscape (Figure 3).

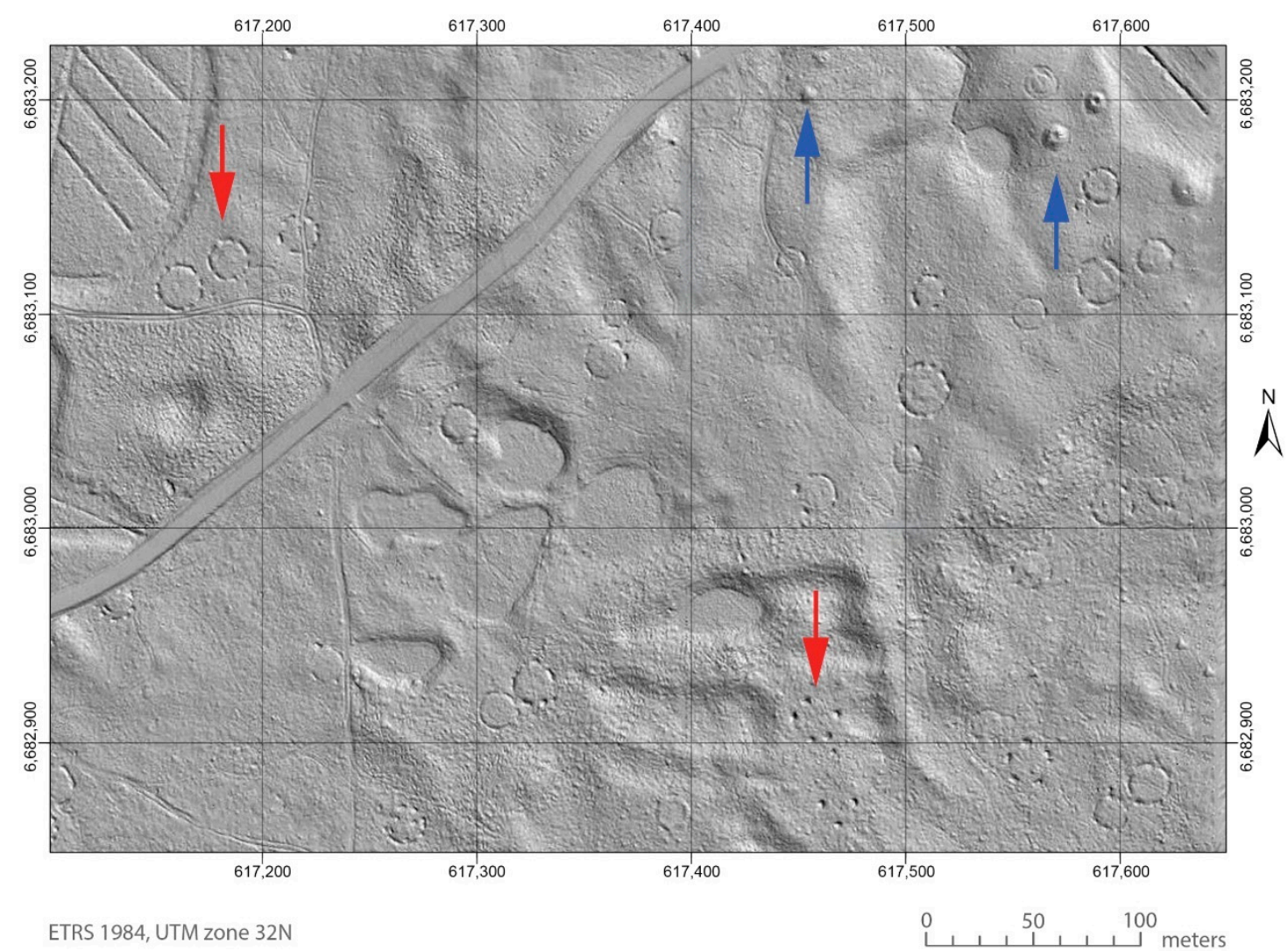

Figure 3. This example from the Eidsvoll municipality shows a section of a forest holding a large number of cultural features, in this case mainly charcoal kilns that appear as solid and dotted-lined circles spread across the area (examples are indicated with red arrows). A few burial mounds appear as convex features at the upper right-hand part (examples are indicated with blue arrows). The presence of modern roads and drainage ditches (herringbone pattern in the left-hand corner) is also apparent. The high density of charcoal kilns in this area is due to the nearby Eidsvoll ironworks, established in 1624 and operational more or less continuously until 1822 [46,47]. (Illustration: Ole Risbøl).

The pioneering studies immediately demonstrated the suitableness of ALS to improve this situation, where numerous cultural features like charcoal pits, iron production sites, tar production sites, pitfalls, and dwelling sites have been identified and mapped $[6,48]$. The identified features were mapped with considerable geometrical precision, a benefit of ALS that also allows for a quality 
assurance of mappings made in pre-global positioning system (GPS) times [48-50]. In addition, these studies showed how each feature could be measured in detail with substantial accuracy based on a DTM imported into appropriate software [51,52].

Thus, the efficiency of ALS was evident from the very beginning, but soon the obvious question arose: To what extent is this a well-qualified approach to identify and map archaeology? The answer to this question is multifaceted but a general methodological approach has been used following four basic steps: data acquisition $>$ interpretation $>$ field verification $>$ statistical analysis. This is a commonly used approach in ALS projects and has led to an aggregation of a quite substantial quantitative data set over the years. The main objective of these studies was to examine the success of detection and the effects of a variety of parameters. The impacts of data resolution have been studied at different scales. In one study, the point densities covering two charcoal pits-one that was well depicted and one that was poorly depicted-were calculated [6]. In the first Norwegian ALS project from 2005, infrared orthophotos were commissioned together with the ALS data in order to obtain more information about the vegetation in the area scanned. Infrared imagery offers the possibility to classify vegetation based on the amount of chlorophyll. In another study, the point density was examined related to 46 identified and 16 omitted charcoal pits [48,51]. Figures from Hedmark County in Norway show that detection success varied considerably, from $21 \%$ to $80 \%$ in three different areas, independent of the types of cultural features available [49]. Last but not least, an extensive study was conducted where four experienced archaeologists were given the task of interpreting a large number of DTMs with point densities of 1,5 , and 10 points $/ \mathrm{m}^{2}$ as well as three different levels of DTM smoothing [53]. The experiment was carried out as a randomized complete block design and the analyses were made using analysis of variance. The study showed a significant improvement in detection success with an increased point density from 1 to 5 points $/ \mathrm{m}^{2}$ and a minor improvement when increasing the point density to 10 points $/ \mathrm{m}^{2}$. The results also demonstrated that the DTM smoothing did not have any significant effect on detection success. In sum, what these studies indicated was not only that resolution matters, but that the effect of point density is not purely exponential, as it has a breaking point at about 5 points $/ \mathrm{m}^{2}$. This has led to a recommendation of using 5-point data when commissioning ALS in Norwegian archaeology [54]. A further conclusion drawn from these point density studies is that dense vegetation is a hindrance that prevents laser pulses from reaching all the way to the ground and it is no use increasing the pulse frequency, as the pulses will be blocked when the canopy is very dense and impenetrable regardless [49,55].

Following the point density examinations, a study of the effects on detection success from the size and the shape of cultural features was undertaken based on the results of the interpretations of the randomized complete block design mentioned above. The cultural features included were charcoal kilns, charcoal pits, pitfalls, various pits, house foundations, tar kilns, burial mounds, and hollow roads [56]. The effects on interpretations based on these features' physical properties (i.e., differences in their size, shape, and elevation) were found to show that detection success rates varied considerably. Unsurprisingly, the figures indicated that large cultural remains with a clear geometrical shape and large elevation difference were much easier to detect and classify than their smaller counterparts, especially those without a clear geometrical shape. Further, the study indicated that increasing the resolution of the DTM first and foremost led to an improved possibility of identifying larger than smaller structures. Increasing the resolution also provided no help in improving the identification of irregularly shaped cultural remains.

As mentioned above, in the first Danish ALS project, Celtic Iron Age fields were studied in a fairly simple way. In the later investigations from 2015, the usage of ALS data was refined and, on the island of Fyn, a 2007 DTM of a hillshade was investigated systematically in order to detect more Celtic fields in the area [34]. Prior to this subsequent study, the number of registered field systems counted only four sites. After the interpretation of the DTM, the number increased considerably to 45 sites, all confirmed by ground observations. 
A study reviewing the late archaeologist Viggo Nielsen's many years of mapping the Geelskov Celtic field system on Sjælland [8] showed that around $80 \%$ of the already recorded field system could be recognized on the DTM without setting foot on the ground [57]. The degree of coherence between Nielsen's previous mappings and the recent DTM interpretations could probably have been even higher if we consider the fact that 60 years separated the two mappings, a passage of time in which modern forestry may have damaged some of the field systems.

The first Danish ALS study anchored solely in archaeology was carried out in late October 2010. It was commissioned as part of the aerial archaeological project "An aerial view of the past" in $2010[36,58]$. It represented an early test initiated with the purpose of studying what high-resolution ALS mapping might add to the detection of archaeological features. The campaign covered $65 \mathrm{~km}^{2}$ in total, divided into five individual test areas. The test areas included both cultivated landscapes and plantations. The point densities were adjusted to the test areas, i.e., the open land was mapped with 28 points $/ \mathrm{m}^{2}$, whereas the plantations were covered with 45 points $/ \mathrm{m}^{2}$. In comparison, the available national scan had only 0.45 points $/ \mathrm{m}^{2}$, so it was obviously an immense improvement in quality. The results in the open land were somewhat disappointing. While a much more aesthetically pleasing hillshade was produced, the archaeological findings were limited. The increased level of detail merely added more visual noise to the model in the shape of modern cultivation traces. A curious finding was that increased grass height over a medieval moat was detectable. As is well-known thanks to a century-long history of aerial archaeology, such cropmarks develop over buried features, including pits, postholes, and moats during times of drought. When vegetation is put under stress, it can result in visible patterns of variation in color and growth height-known as cropmarks—where buried humid soil is found [58].

A much better result was obtained in the Klosterheden plantation, situated in a largely uncultivated heath landscape. The models based on 0.45 points $/ \mathrm{m}^{2}$ from 2007 had poor penetration owing to the presence of dense spruce trees (no information exists regarding the period of the year in which the scans were conducted). The high-resolution scan completely opened the view into this virtually fossilized landscape, even though the increase in newly identified burial mounds and Celtic field system was limited. This was expected because the area consists of poor and wet soils, unattractive for settlement and cultivation. However, what was found was the total accumulation of road tracks and sunken roads, probably from prehistory and onwards. The overall pattern of transport uncovered a shortcut of the so-called Oldtidsvejen ("Prehistoric Road"). The name refers to a 110-km-long alignment of no fewer than 1856 burial mounds, interpreted as a prehistoric and historic travel route from east to west [59]. At the Klosterheden plantation, the prehistoric road makes a detour around the plantation area. The laser scan revealed that a shortcut of no less than $6 \mathrm{~km}$ existed, although this would only have been feasible in the dry summertime [36]. The conclusion of the test project was that the ultra-high point density was fruitful in dense spruce tree plantations.

Alternative visualization methods like local dominance, sky-view factor, and local relief model have seen limited use in archaeology in Denmark, although they offer considerable potential [57,60], (Figure 4a,b). Local dominance in particular proved optimal in the very flat Danish terrain. Indeed, for the detection of cultural features, it is probably even better than the usual hillshade. However, to date this remains unknown to most Danish archaeologists. The main reason is likely that the provided hillshade is highly intuitive to the average user. Another factor is that it is a demanding task to process larger areas, requiring skill and applicable software. Nevertheless, the task has recently become somewhat easier owing to a local dominance plugin for QGIS, developed by the Department of Geoscience at Aarhus University (unpublished work). 


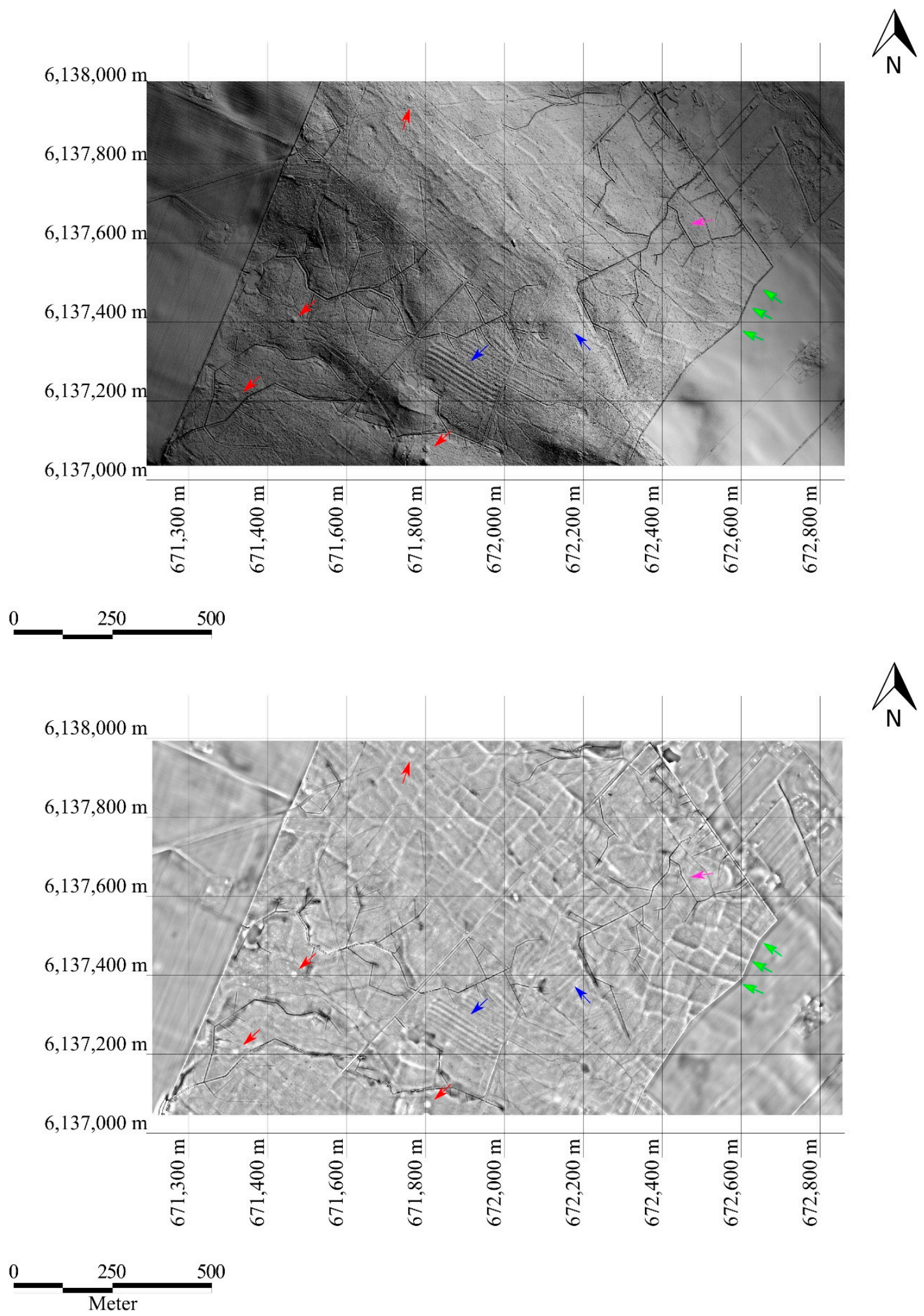

Figure 4. Upper image (A): An example, shown as a hillshade, of the Danish 2015 national airborne laser scanning (ALS) study. The Glumsø Østerskov forest, Næstved municipality, covers archaeological features such as Neolithic megaliths, a Celtic field system, and traces of Medieval ridge-and-furrow cultivation, all superimposed by modern drainage ditches. As the Celtic fields are situated on both 
sides of a ridge the hillshade visualization is not optimal, as some areas are over- or underexposed, regardless of the direction of light. Lower image (B): Same as above but pictured differently due to the use of the local dominance visualization method. The Celtic fields are much more visible than in the ordinary hillshade. Examples of burial mounds are indicated with red arrows, ridge and furrows with blue, field boundaries with green, and modern drainage ditches with purple. (Illustration: Esben Schlosser Mauritsen).

A recent study from the Forestry Research Institute of Sweden (Skogforsk) has examined the use of ALS for heritage management within the forestry sector [61]. The study involved three interpreters with different backgrounds: an archaeologist, a forester, and a civil engineer in environmental techniques. They were given the task of interpreting ALS data consisting of terrain models in hillshades and multiple hillshades generated from national ALS data interpolated to $+1 \mathrm{~m}$. The test focused on different geographical areas and the results of the interpretations were validated in the field. The study concluded that the data were useful with regard to detecting sites, but that training is necessary before they might be successfully used by forestry planners.

In Sweden, early studies mainly focused on the use of ALS to identify, record and map sites. These studies usually followed the four basic steps mentioned above. In 2011, a survey was undertaken in northern Sweden as part of the larger collaborative project "Skogens kulturarv i Kvarkenregionen2" [62]. This represented one of the earliest projects in Sweden using ALS on a more operative basis as part of a wider cultural heritage project. A field evaluation in the first year showed that $75 \%$ of the features identified in the ALS data were confirmed in the field as true positives. The majority of the identified features were trapping pits, charcoal kilns, clearance cairns, and tar kilns. House foundations proved difficult to detect [63]. Using ALS data during or prior to archaeological surveys has constituted a growing trend among archaeologists since the release of low-resolution ALS data by the Swedish Mapping Agency. In the county of Jämtland, ALS data were used in a test in 2013 as well as in several surveys from 2014, reporting satisfying results and proving cost-efficient [64]. In many of the mid- and northern Swedish surveys using national ALS data in the first part of the 2010s, there was a clear bias concerning the type of sites most frequently identified in the data, usually being skewed towards features such as charcoal kilns and trapping pits. In a survey in Skogs parish in the county of Hälsingland, nearly $100 \%$ of the charcoal kilns indicated in the terrain models based on national ALS data were verified through fieldwork. Using ALS data with other resources such as orthophotographs has been deemed especially useful. Furthermore, combining ALS data with historical maps has enabled deeper insights into the historical landscape [65].

In 2014 and 2015, the Swedish National Heritage Board looked into the possibilities of using remote sensing techniques to correct the spatial data quality in the digital archaeological sites and monuments record (Figures 5 and 6). This included exploring whether corrections could be made based on automated design engineering. Key reasons behind the project were the growing demand for accurate site data and the upcoming launch of a new cultural heritage database, the Kulturmiljöregister. The timing of the project was also coherent with the release of new products built on national ALS data. The geo-consultancy firm Metria was contracted to examine the possibilities and the result was presented in two reports $[66,67]$. The study concluded that automatic approaches at the time were technically demanding and would be accompanied by a significant degree of uncertainty compared to manual interpretation and editing. The report further suggested that a GIS platform combining remote sensing-based data with other geographical data (e.g., historical maps and geological information) would improve manual correction and provide advantages to cultural heritage management in general [66]. There have been no further moves to study remote sensing applications for site correction or cultural heritage management by the Swedish National Heritage Board. How ALS can be utilized to improve the accuracy of the geographical positioning of previously mapped cultural features has been demonstrated in Norwegian publications $[49,50]$. 


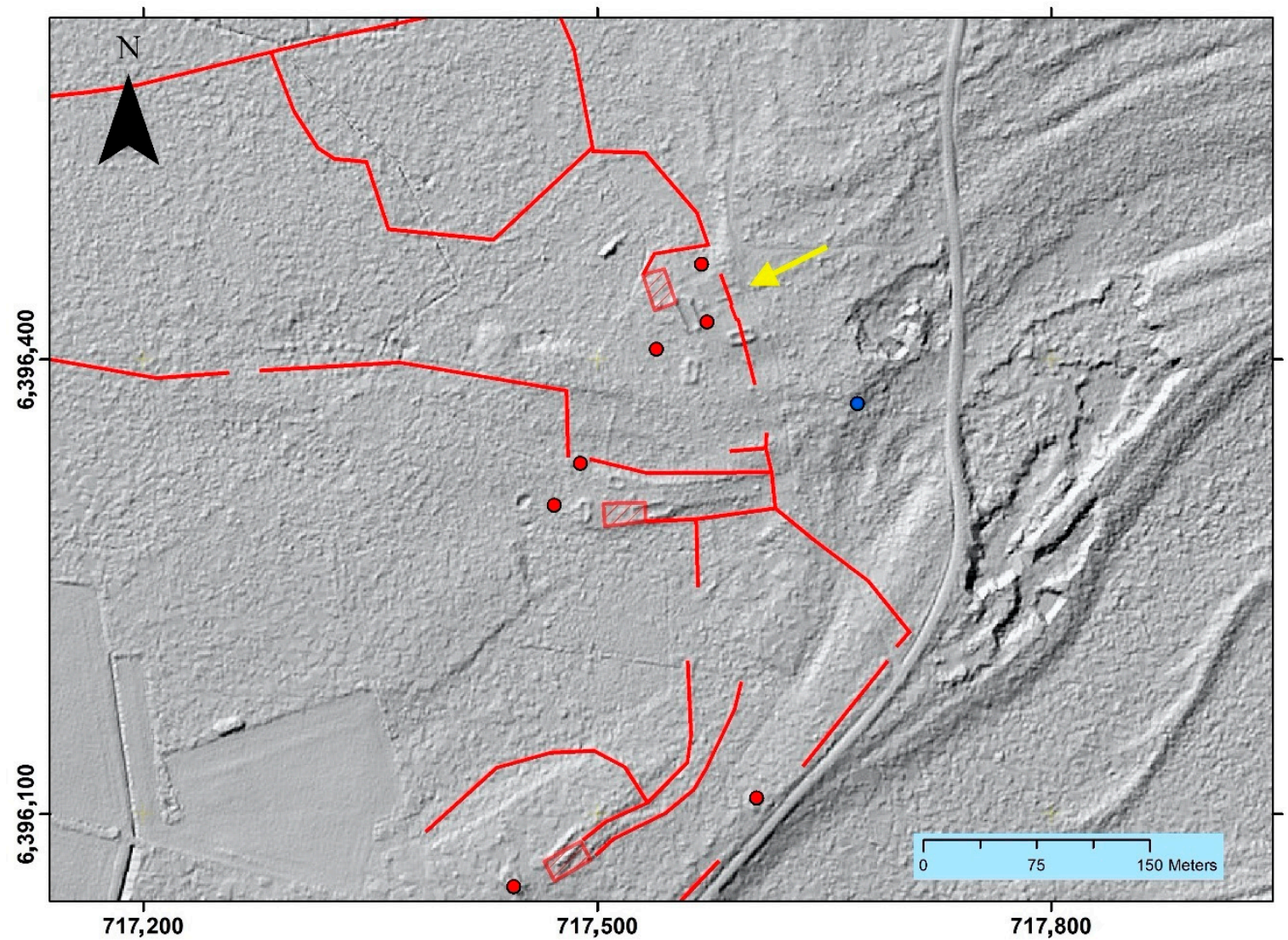

Figure 5. Aränget (Bäl parish, Gotland). Iron-Age house foundations and stone fences enclosing farmland. Orange rectangles and red dots show the geographical location on maps in the national sites and monuments record. It is obvious that they all have a slight offset to the west-northwest compared to their more precise location on the ALS-generated (digital elevation model (DEM). The yellow arrow marks the location of the house foundation in Figure 6. The image illustrates the importance of ALS data for spatial site correction. Coordinates: SWEREF99 TM (Illustration: Daniel Langhammer). (C) Lantmäteriet Geodatasamverkan.

Few Swedish studies have used high-resolution ALS data for comparison with low-resolution national coverage data. An interesting contribution was presented in a paper from 2019, focusing on the detection of cultural heritage sites in boreal forests. The study area was Krycklan, located in north-western Sweden. The study compared the national ALS data set with a density of $1.1-1.3$ points $/ \mathrm{m}^{2}$ (the density in the specific area) with a data set with an average of 13 points $/ \mathrm{m}^{2}$. The DTM grid used $0.4 \mathrm{~m}$ for the higher-resolution data and 0.7 for the lower-resolution data [68]. Unsurprisingly, the higher-resolution data exhibited greater detection success concerning certain types of sites, such as charcoal kilns and tar production sites, as proved by the earlier tests in Norway mentioned above. Some features, like subtle ruins from dwellings, were rather difficult to identify successfully even with the higher-resolution data, while in the lower-resolution data they were almost unrecognizable [68]. Studies of this kind are interesting, but it is important to recognize that the transfer value to other geographical areas is limited because the outcome is dependent on a series of parameters, such as period of flight, local topography and vegetation. If the same study were to be conducted in an environmentally distinct county like Gotland, for example, good results would be expected in terms of identifying very different features, such as house foundations from the Roman Iron Age as well as prehistoric field systems. 


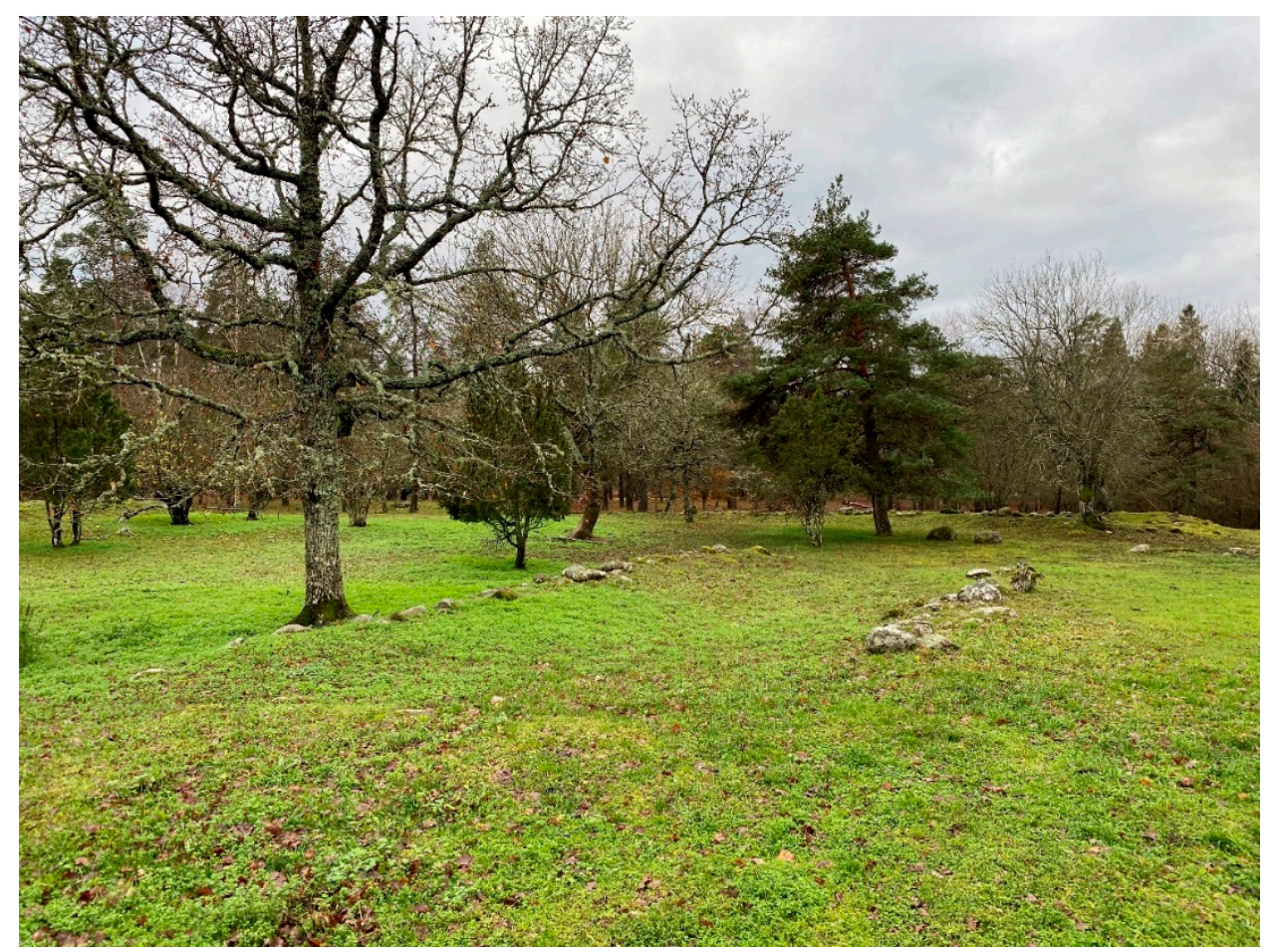

Figure 6. Aränget (Bäl parish, Gotland). The house foundation (east-west) located furthest to the northeast, outlined by the stone walled foundation. Its location is marked by a yellow arrow in Figure 5 . In the background another of the house foundations (northwest-southeast) is slightly visible. This type of house foundation generally dates from between AD 200 and 600 based on excavation, with a few exceptions extending the timespan. Photo: Daniel Langhammer, 2019.

Archaeologists in Finland started applying ALS in their work immediately after data became available, although initially the issue of data availability defined where ALS-based work could be undertaken. FNLS scanning campaigns commenced in areas that were at risk, such as coastal flood-risk regions, or areas with special infrastructural needs, such as the Helsinki metropolitan area. Owing to data availability, the 20th-century military structures on the southern coast became the focus of the first ALS-based studies. The initial publications concentrated on describing the potential of ALS data and the various methods that could be used to visualize and analyze them, with various kinds of military camps, defensive lines, and Stone Age sites operationalized as examples [11,12,69]. As mentioned above, the FNLS open-access data are rather coarse, with point clouds of about 0.5 points $/ \mathrm{m}^{2}$ and 2-m DEMs based on those. Typically, archaeologists have used point cloud data to interpolate 1-m-resolution DTMs for their study areas, before visualizing these further with other methods, such as sky-view factor and local relief models [69], (Figure 7). In some areas, Finnish archaeologists have been able to utilize more detailed ALS data available through cities and municipalities, universities, and the FNBF, but these high-resolution data are limited in terms of their spatial extent. Recent large-scale archaeological survey projects carried out by the FNBF in forest regions in 2010-2015 as well as the Swedish-Finnish project "Skogens Kulturarv i Kvarkenregionen" employed FNLS ALS data across large landscapes to successfully direct field studies [70,71].

After the first papers from 2010-2013, no specific methodological or technical studies or new developments were made in Finnish ALS use for several years. The ALS data have been mostly employed implicitly as just another open-access data set that can direct fieldwork. However, in 2018-2019 an international team working in northernmost Finland started exploring the potential of semi-automated site recognition and various types of remote sensing data to enhance the potential of ALS data per se (see below) [72]. 

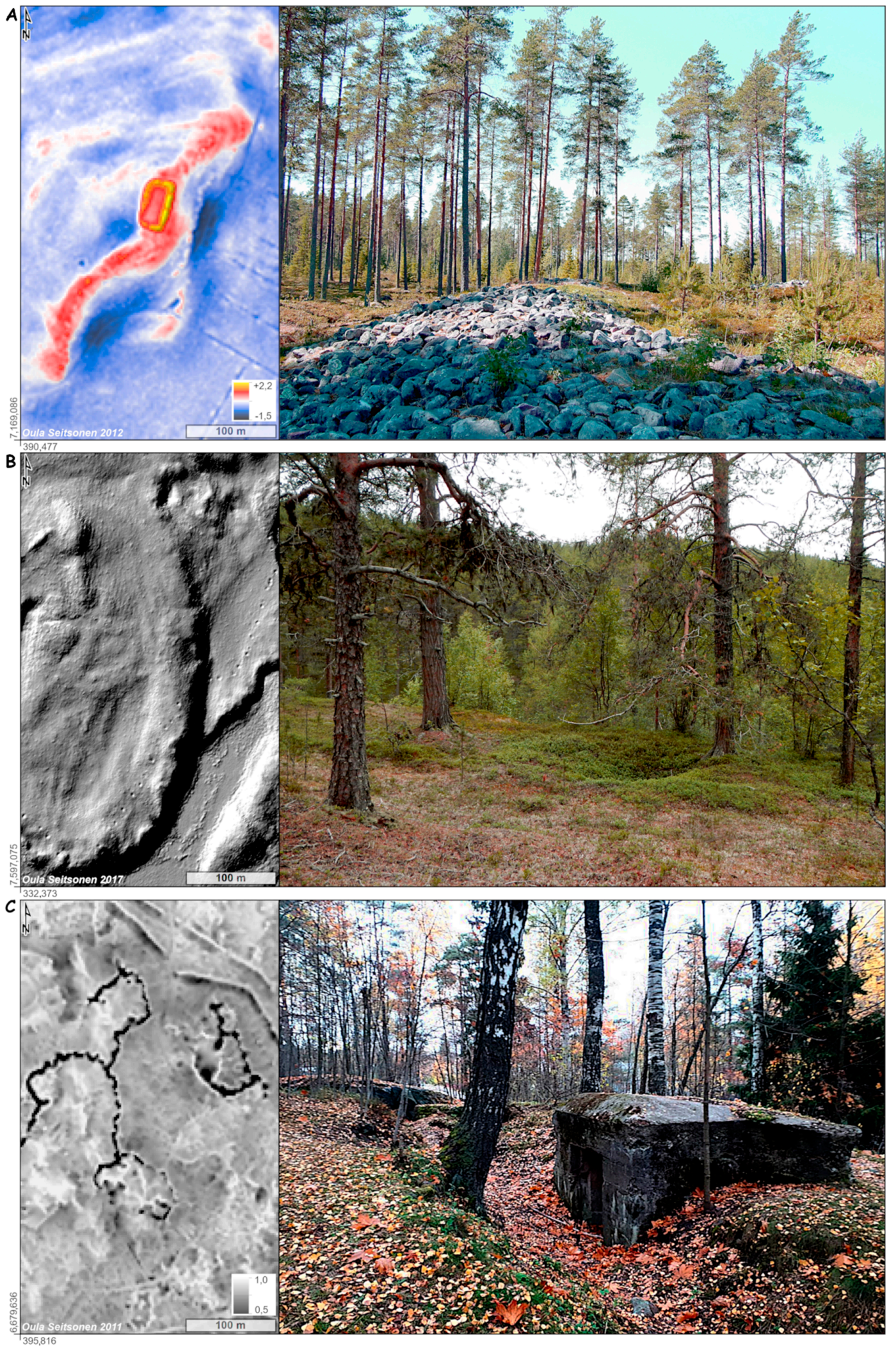

Figure 7. Visualizations and photographs of selected sites (in Finland) based on the open-access ALS data from the Finnish National Land Survey (FNLS). (A) Local relief model of a Late Neolithic "Giant's 
Church" structure and adjacent cairns and housepits at Kastelli (Photograph public domain, Wikimedia Commons/Estormiz). "Giant's Churches" are megalithic drystone-walled ritual and/or defensive structures from the Finnish western coast. Note the "gateways" visible on the perimeter wall (see also Figure 11). (B) Multi-directional hillshade of a Sami pitfall trap system near Kilpisjärvi. (C) Sky-view factor presentation of a First World War trench system near Helsinki (EPSG:3879 ETRS89/GK25FIN). (Illustration: Oula Seitsonen).

\subsection{ALS and Cultural Heritage Management}

Many archaeologists are involved in cultural heritage management and are occupied with what is termed development-led archaeology or rescue archaeology. Their key responsibilities are to mitigate the negative consequences of development projects by safeguarding important archaeological sites and monuments from intervention and to secure archaeological source material through excavations. This requires good archaeological records combined with archaeological surveys as part of the cultural heritage management measures carried out ahead of development enterprises.

The employment of advanced technology has become increasingly common in cultural heritage management in recent decades, necessitating evaluation of its outcomes and further potential. In 2013, the Norwegian Public Roads Administration funded a pilot project with the aim of assessing the use of advanced archaeological methods and their potential use in connection with road development projects [73]. The purpose was to consider the extent to which such methods can replace (or more likely supplement) conventional survey methods as well as how best to streamline the surveys without reducing the quality of the cultural heritage management process. Planning authorities and developers often obtain access to crucial information relevant to land use at a late stage in the process, creating unpredictability in relation to progress and cost.

The pilot project involved an assessment of the following remote sensing techniques: satellite imagery, aerial photography, ALS, hyperspectral scanning, and geophysical survey methods. These were evaluated in terms of their relevance, utility, and efficiency in relation to parameters such as landscape type, archaeological features, and management plan level. Such relatively new non-invasive methods have the potential to cover large areas in a short period of time, an important quality at a primary plan level (see also $[49,50]$ ). ALS is especially beneficial in forest areas, where due to its vegetation-penetrating properties it is very suitable for mapping visible cultural features. Furthermore, it can be used advantageously in other types of landscapes, such as mountain areas and wetlands. It has been argued that ALS is not a perfect substitute for conventional fieldwork, but it can be a priority tool for selecting particularly interesting areas, increasing the efficiency of the fieldwork [73]. Using this technology, one can attain a rough overview of the cultural heritage stock in a large area in a short time and with a high degree of safety and precision. Thus, one has a good basis for directing the fieldwork and doing it more effectively.

In the pilot project report, it is emphasized that it is not the particular method or the individual data set that will provide the answers, but rather overall access to information from the set of different methods. Information about archaeological heritage can be collected in a GIS and geodatabase that provides a better basis for making overall assessments and thus well-qualified decisions. The importance of ensuring greater predictability regarding land use and possible conflicts with archaeological sites' cultural heritage is the goal. For the beneficiary, the main benefit is not primarily the efficiency of the fieldwork, but predictability and getting the necessary overview as early as possible.

Although substantial knowledge has been accumulated on the use of digital archaeology, there is a need to conduct systematic comparative studies of the actual efficiency of different methods with respect to the detection of archaeological traces and their cost-effectiveness. No projects have been carried out to highlight the benefits of integrated approaches. There is a need to move on from good but scattered single results to overall examinations that adopt the entire archaeological toolbox.

County administrative boards are the main agencies that administer, manage, and monitor archaeological sites and monuments in Sweden. There are 21 individual agencies, one for each 
county. The work is diverse, including decision-making concerning heritage management, conducting archaeological surveys and excavations prior to development plans, conservation, and much more. In daily work, GIS resources are vital for efficiency and constitute the backbone of basic landscape or site analysis, necessary to determining the approach to take in any case. ALS data are available either through a GIS web service or through a catalogue for desktop applications. For many officials, the use of ALS data is restricted to pre-modelled terrain models (hillshades or slopes) from the web service and they have no or limited knowledge of the background data or processing involved. Nevertheless, national ALS data have proved very useful in multiple ways. As mentioned above, ALS has been carried out on a national scale in Sweden since 2009. Back in the early days, archaeologists in some cases used 2-m raster images rather than interpolating models from the point cloud data at a slightly higher resolution, exploring the density of the specific scanning area. The reason for this may be multifaceted, involving the learning curve when dealing with new data, GIS and software experience, knowledge of the availability of different data sets, and so forth. Later products by the National Mapping Agency have been interpolated to $1 \mathrm{~m}$, including data provided by WCS that allow the user to download raster images. In this short period of time, ALS has had an impact to various degrees on archaeological surveys, landscape analyses, and heritage management. ALS greatly contributes to the existing toolkit of the archaeologist by offering detailed spatial data that simply were not available or affordable in the past. When conducting a search among archaeological suvey reports, it is obvious that national ALS data are used more and more frequently from about 2015 and onwards to identify sites as well as to predict where they are located based on digital reconstruction of the ancient landscape (e.g., changed shorelines).

The County Administrative Board of Dalarna in Sweden has been running a project with the aim of protecting Swedish summer farm sites (fäbodar), with the farms mapped by combining ALS and historical maps. The purposes are to aid forestry planning and to record sites in the archaeological sites and monuments record. When dealing with historical agricultural sites, it is not unusual that anomalies may correlate with the old landscape features once drawn by a land surveyor on a historical map, rendering the ALS useful for accurate map rectification. Features correlating between the data and the map may include traces of fields or field systems, such as field terraces/terraced corners or ditches [74].

Another example comprises the Iron Age Celtic fields on the island of Gotland, many of which are well preserved, especially in forested areas. These sites are defined by low and sometimes wide linear earthworks enclosing square or rectangular fields and may cover large areas (Figure 8). Given their geometric regularity and adjoining patterns, they are easy to detect in ALS when the conditions are right. From the ground view, these fields might be hard for untrained eyes to detect, especially in a forested environment (Figure 9). Even experienced registrants might have a difficult time under field conditions. Although national monument surveyors can work fast, the introduction of ALS has shown that many of the fields have a smaller extension in the national monuments record than in reality (if recorded at all). In such cases, ALS also possesses a pedagogical value as it is possible to show an image of the extent of the site and provide the geographical orientation of features that may later be identifiable on the ground. This has been useful when communicating the location of protected sites prior to tree felling and reforestation measurements. 


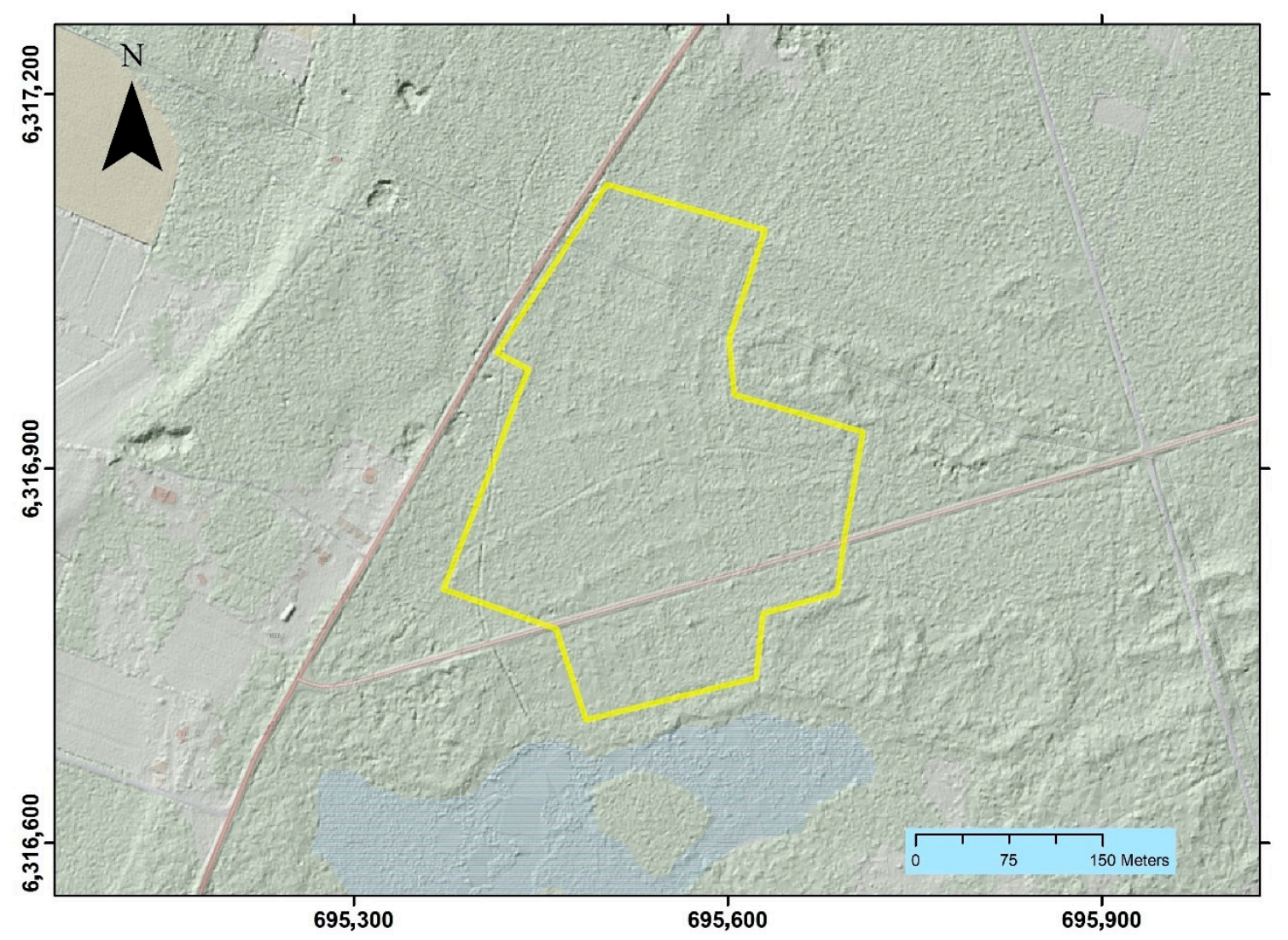

Figure 8. Sundre parish, Gotland. The yellow polygon encircles unrecorded Celtic fields. The eastern part of the encircled area has recently been subjected to tree felling (after the ALS survey). The earthworks in this part were hard to detect at field inspection due to the work done in the area. The western part was also subjected to forestry and reforestation a few decades ago. In this part the earthworks were well preserved. In this case, ALS is an important indicator to the state of preservation before felling. Coordinates: SWEREF99 TM (Illustration: Daniel Langhammer). (C) Lantmäteriet Geodatasamverkan.

In 2016, the County Administrative Board of Gotland funded a project combining ALS and field surveys of five ancient field systems located in woodland areas [75]. The study sought to attain a better understanding of how ALS might be used to define the extent of the field systems so that they could be recorded in the national monuments record. This is important because many are preserved in areas with productive forests [75]. The study concluded that ALS-based interpretations were in many cases sufficient to define the extent of the field systems. Field observations proved to be a necessary complement to ALS analysis in some areas, especially when the earthworks separating the fields were low in height and situated on uneven topography. By contrast, ALS proved superior to ground observations in areas that had been clear-cut, subjected to soil scarification, and were then overgrown with low and dense vegetation [75]. These are examples with good results, but of course less successful results have been reported as well [76]. The reason is usually multifaceted and may be explained by different parameters such as resolution, data processing, local topography, vegetation, and site morphology. 
The majority of ALS studies have been undertaken in woodland areas where preservation conditions are more advantageous than in arable land. This factor combined with the lack of cultural heritage survey data from forested areas is the obvious reason why ALS with its vegetation-penetration abilities has found its most successful use in woodlands. Thus, challenges at the intersection of forestry and safeguarding cultural heritage have become a priority. How ALS can play a role in sustainable forestry, including the improved safeguarding of cultural heritage assets, has received considerable attention [45,49,50,77-79], as emphasized by studies indicating that a large percentage of cultural features in woodlands is destroyed or damaged by forest-related activities [40]. This has accentuated the rationale of devoting attention to how ALS can help to improve the situation.

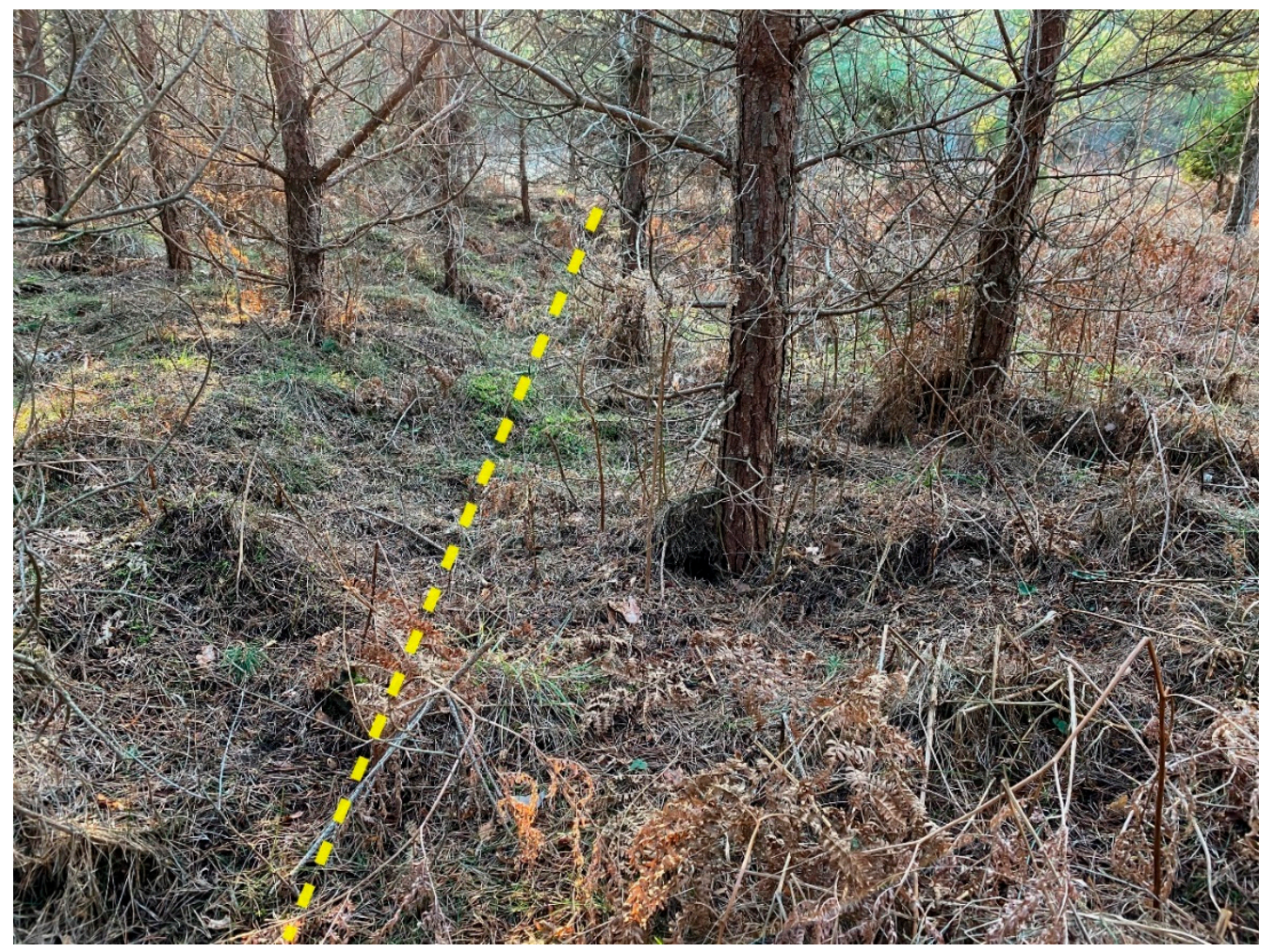

Figure 9. Sundre parish, Gotland. The yellow line marks the lower edge of an earthwork (i.e., field enclosure). The earthwork is approximately $0.4 \mathrm{~m}$ high and about 7-8 $\mathrm{m}$ wide. Such features might be hard to detect during forestry. This part of the field system was subjected to reforestation a few decades ago. Photo: Daniel Langhammer, 2020.

\subsection{Semi-Automated Detection of Cultural Features}

The manual, desk-based interpretation of DTMs represents the most common way of utilizing ALS data within archaeology. This is a time-consuming task, especially if very large areas are studied. This has led to the deployment of semi-automatic methods based on the use of algorithms developed for template matching. An early plain test using pattern recognition based on template matching was carried out with convincing results in 2008 [80]. The Norwegian Computing Centre has undertaken comprehensive pioneering work on a semi-automatic approach for the detection and mapping of cultural features in ALS data. These studies have targeted various human-made pits and mounds in quite large geographical areas, including pitfalls and charcoal pits [81-83], burial mounds [84], and charcoal kilns [85]. They are based on template matching, an approach that is dependent on knowledge of the properties of the archaeological features being targeted [86]. This requires the development of specific algorithms for each object type, a circumstance that hampers the general semi-automated detection of archaeology. This, together with difficulties pertaining to the identification 
of heterogeneous archaeological features as well as the need to involve a high level of expert knowledge and costly software, has prevented the widespread use of the approach. However, recent advances within artificial intelligence (AI) and machine learning have led to deep learning using convolutional neural network (CNN) algorithms [87]. Machine learning and CNN offer the potential for a more general approach to the automated detection of archaeological features, as they address challenges related to the development of specific algorithms for each type of archaeological object. With a pre-trained data set based on millions of images, one can carry out final training on known archaeological structures like charcoal kilns [88]. Thus, machine learning, deep learning, and the employment of CNN have helped to advance the semi-automatic detection of targeted features in large ALS data sets. Their potential has not been fully explored, although quite a large proportion of research and development related to ALS and archaeology is concerned with exploring this [89-91]. A pilot web portal, CultSearcher, for the semi-automatic mapping of some types of cultural features (grave mounds, pitfalls, charcoal pits, and kilns) in ALS data has recently been launched under the auspices of the Norwegian Directorate of Cultural Heritage and will be further developed [92,93].

The discovery of the Danish Viking Age ringfort Borgring on the national hillshade model sparked a search for further undetected forts [94]. To reduce the immense task of a systematic manual search, computer vision algorithms were used in a semi-automated search for additional Danish Viking Age ringforts based on the 0.45 point $/ \mathrm{m}^{2}$ DEM from 2007 [60]. These ring detection efforts initially resulted in the identification of 202,048 circular features, later reduced to 199 sites after further processing by using machine learning (among other means) to classify the cultural and topographic context. These efforts led to the identification of just two potential Viking Age ringforts, both of which were already known and listed in the archaeological record. Thus, what this study seems to demonstrate is that there are most likely no unknown Viking Age ringforts with remaining elevated earthworks to be found that are not already listed in the archaeological record.

Semi-automated detection is far from well explored within Swedish archaeology compared to Norway and other places. To date, one of the most interesting studies consists of a master's degree thesis in Geomatics at the University of Gävle, which used national ALS data to detect charcoal kilns in a limited area in the county of Gävleborg. As mentioned above, the national data have a fairly low resolution (about 0.5 points $/ \mathrm{m}^{2}$ ), but still proved useful for semi-automatic detection. Feature extraction used MATLAB software and algorithms [95]. The test used the $\mathrm{F}_{1}$ score to measure test accuracy, with 0 indicating the worst and 1 the best. This score takes true or false negatives and true or false positives into consideration. The test showed an accuracy of 0.54 in the study area. When filtered by further post-processing, the score improved to 0.71 [95].

In Finland, simple semi-automated methods have been preliminarily tested with 20th century conflict sites [69] and in field school surveys of the University of Helsinki. In Lapland, in an ongoing international project, semi-automated detection of cultural remains took place in 2018-2019 to direct a landscape-level survey of German Second World War military structures in Gilbbesjávri, Eanodat (Fi. Kilpisjärvi, Enontekiö) [72]. The project is based on the methods developed by Rémi De Matos-Machado et al. [96] to map structures on First World War Western Front battlefields. A massive number of previously unknown sites, such as Second World War structures and prehistoric trapping pit systems, have been located based on a combination of ALS, historical and modern aerial imagery, and semi-automated methods. In the Gilbbesjávri case study, combinations of different remote sensing materials were also applied (see below). 


\subsection{Monitoring Cultural Heritage}

Investigations into the potential of using ALS data for monitoring purposes within cultural heritage management are limited, although not untested. A Norwegian paper from 2008 addressed remote sensing as an applicable methodological tool in the monitoring of cultural features, environments, and landscapes [97]. The potential of the three most relevant remote sensing techniques (aerial photos, satellite imagery, and ALS) was discussed separately and subjected to comparison with a certain focus on their strengths and weaknesses. As opposed to the passive nature of aerial photos and satellite imagery, ALS is an active method, emitting laser pulses that travel to the ground surface and back. It was concluded that ALS-generated 3D models are well suited for performing change detections. These are automated comparisons of two data sets from the same area collected at different times. By doing so, one can identify where changes have occurred from one period of time to the next, a fundamental reason for monitoring. The possibility of working with $3 \mathrm{D}$ data and the vegetation penetration ability of ALS render it an advantageous approach to cultural heritage monitoring projects targeting large geographical areas as well as those covered with vegetation. Thus, it is possible to monitor changes to land use, cultural monuments, features, and objects based on ALS coverage alone or in combination with the other remote sensing techniques addressed in this study.

Watercourse regulations with the purpose of energy supply represent a challenge for cultural heritage management. They are subjected to constant landscape changes due to erosion, sedimentation, and so forth, circumstances that call for condition assessment and the monitoring of cultural remains and environments along these waters. In a paper from 2011, the opportunities available to use ALS as a method to map, identify, and monitor prehistoric cultural monuments along lakes and rivers that have been subjected to waterpower regulation were discussed based on two case study areas [98]. The study indicated that ALS is well suited for the detection of sites within and above the edges of erosion, but less suitable within the erosion zone. For environmental monitoring, ALS is a suitable method for use in all zones, but it requires that the location of the cultural remains and sites is known. When the localization and the distribution of the objects are known, they can be monitored visually on a digital terrain model and in combination with automatic change detection in order to document erosion and sedimentation. It was concluded that although ALS as a method has its limitations, it is an applicable tool to detect, document, map, and monitor cultural remains and sites in regulated lakes and rivers, especially if this is done in combination with conventional fieldwork.

In monitoring projects, data analysis based on long time series is desirable, as it provides the best basis for identifying and understanding current change-related processes as well as facilitating analysis in the years to come. Given that ALS is a relatively new method, the availability of ALS data is limited, being confined to the last decade or two. This challenge has led to the idea of combining newly acquired ALS data with historical aerial photos, with the purpose of performing what one might call retrospective monitoring. Thus, a case study was initiated based on data from the protected cultural environment of Mølen in south-eastern Norway, which is a well-known cultural heritage site with more than 100 pebble-stone grave cairns of various size and shapes [99]. Historical aerial photos and ALS data from two campaigns were subjected to change detection analysis and the results were discussed in relation to written sources from archives. The archival sources were informative in terms of determining the causes of change, while the aerial photographs and the ALS-generated DTMs helped to detect the grave cairns and to document the changes they had undergone. The study revealed that most of the cairns had been subjected to change during the last 200 years, based on a plain approach using varied historical data in combination with recently acquired ALS data.

This study was followed up by a new and technologically more advanced study of the Mølen site. In this study, georeferenced DEMs were generated for the years 1968, 1979, and 1999 using historical aerial photographs [100]. In addition, two ALS data sets from 2008 and 2010 were used in the study. Seven difference models were generated as a result of conducting automated change detections between the different years of footage, resulting in detailed information about the changes that occurred to individual monuments and their surrounding environments over the last five decades. 
As in the previous study, the incidents that caused the identified changes were interpreted based on the actions described in archived documents. In this way, the dynamic character of the studied site was proved, along with the fact that historical aerial photos represent a valuable source facilitating the retrospective monitoring of past landscape changes on a detailed scale.

In arable areas, annual ploughing continuously levels local terrain by moving soil from higher ground downslope. The impact on buried archaeological remains located on higher parts of arable land can be devastating. In north-western Sjælland in Denmark, a study was conducted in order to document this process [101]. The test focused on whether the two available national DEMs in Denmark from 2007 and 2015 could be used to document the erosion of the ploughed landscape. The study showed that systemic errors caused by the acquisition of the data superseded the erosion when assessing areas larger than $500 \times 500 \mathrm{~m}^{2}$ or even less, depending on the flight lines. However, it is debatable whether in a case study covering just 15 hectares it is possible to detect erosion of $5-20 \mathrm{~cm}$ over the course of the seven years separating the two national DEMs [101].

The Swedish Civil Contingencies Agency has used ALS data to analyze the risks and impacts of rising sea levels. One part of this analysis, undertaken in collaboration with the Swedish National Heritage Board, examined the possible impacts on protected archaeological sites and monuments. The results showed that 44 out of 105 sites in a study area would be affected by a sea level rise of 0.2-1.2 $\mathrm{m}[102,103]$, but it must be stressed that the specific area chosen has a very low elevation above sea level. Thus, the study demonstrated how ALS data might be combined with national heritage data to create models that could be used in contingency planning.

\subsection{Combined Use of Remote Sensing Techniques}

The digital toolbox (including remote sensing platforms, techniques, and methods) available to archaeologists is continuing to grow. Each technique has its advantages and disadvantages and so a multi-method approach involving more than one platform or technique is often desired. For instance, in open or semi-open landscapes, it is usually preferable to combine several remote sensing techniques. Where ALS yields topographical reproduction, aerial photography or satellite imagery offer clues as to other important information, such as changes in vegetation and the color of plants or soil that might indicate archaeological sites [104]. The visual input from photographic imagery may also assist in the interpretation of ALS images due to the fact that historical orthophotographs sometimes help explain traces of landscape change visible in the ALS data. On the other hand, ALS helps to interpret topographical anomalies and to understand the location of a site in its wider landscape. A combined approach may prove even more powerful when using additional historical sources, such as historical maps.

In a study in northern Norway, the combined use of aerial photos, satellite imagery, and ALS data is currently being carried out in an area with numerous pitfalls for reindeer catching found in clusters (Figure 10). So far, this work can report that analyses of aerial and satellite imagery as well as ALS data have shown convincing potential to improve knowledge about archaeology in a landscape like the Northern Cape, especially when combining the three sets of remote sensing data. In the same landscape, house sites, stone circles, and mounds have been found, all from Sami activities [105]. 


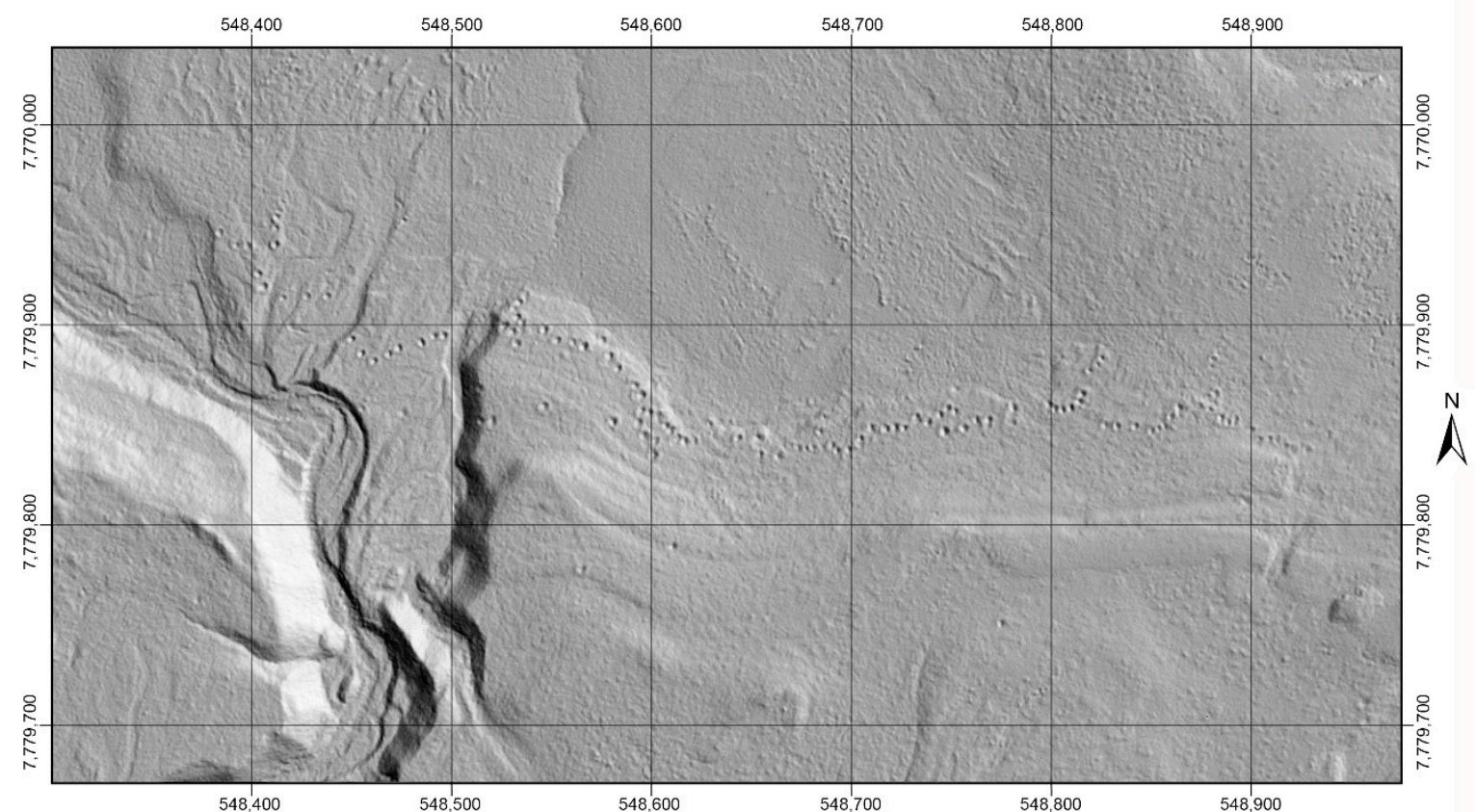

ETRS 1989, UTM zone 35N

A
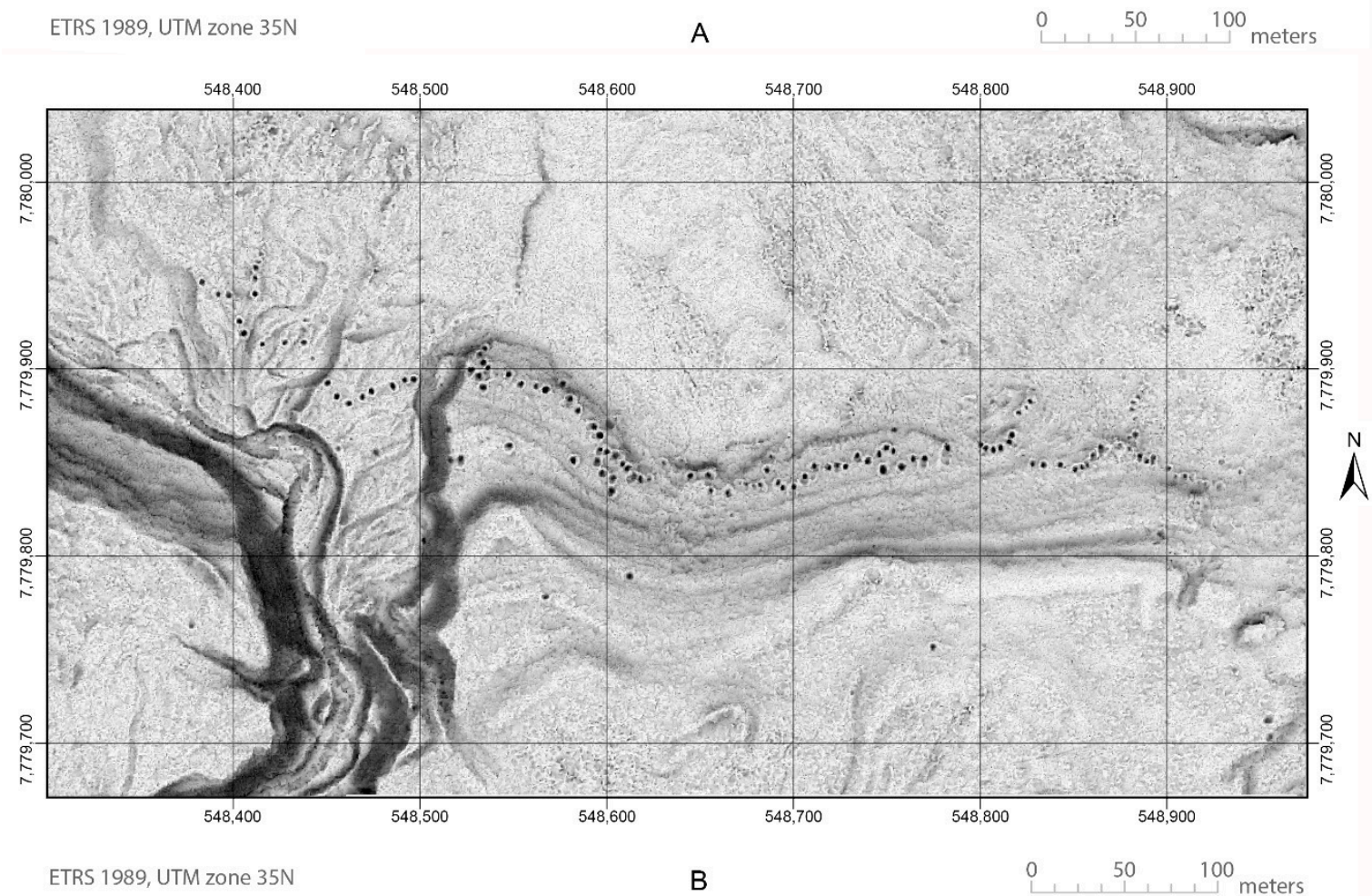

Figure 10. A section of a large system of hunting pits (pitfalls) at Gollevarre in Tana municipality, northern Norway (upper image, A). The pits are particularly visible at in the lower image (B) where they stand out as black spots located like pearls on a string with an eastern-western course. The total system consists of more than 800 aligned pits reaching several kilometers across the landscape [106]. The upper image is a digital terrain model (DTM) and the same section is visualized in the lower image by the use of the sky-view factor visualization technique [107]. (Illustration: Ole Risbøl). 
In 2015 a workshop was held in Trondheim on the subject of early iron production as well as how such sites can be identified and investigated through remote sensing [108]. In this case the notion of remote sensing was used as a collective term, covering geophysics as a ground-based remote sensing method and ALS as an airborne remote sensing method. The rationale for arranging the workshop was to gather researchers with experience of working with pre-industrial iron production and using remote sensing techniques as a way to identify, delineate, map, and type designate such sites. Traces from early iron production have been found in great numbers in outfield areas and the introduction of ALS in archaeology has offered new possibilities to survey these in a productive manner. The extent to which this is valid has constituted the focus of a study examining how the interpretation of ALS-generated DTMs can benefit from the use of supplementary visualization methods like the local relief model and sky-view factor [109]. Several such visualization methods have been developed for archaeological purposes in recent years [110]. A study concerning the advantages of adopting visualization methods was established to assess detection success when two test persons were assigned the task of interpreting DTMs using various relevant methods. The test targeted slag heaps at iron production sites and additionally included the identification of charcoal pits associated with pre-industrial iron production. The study proved a rather substantial improvement in detection success concerning the features that are most difficult to identify in ALS-generated DTMs when applying additional visualization techniques. The gain was marginal concerning the more easily identifiable charcoal pits. Another finding from the study was the increased number of false positives resulting from the employment of additional visualization methods. Risbøl and Gustavsen's paper [109] also included a short report on the potential of employing airborne magnetometer as an approach to identify iron production sites from the air. This report was based on a test carried out some years back but never completed. ALS has its limitations: for instance, is it often difficult to distinguish human-made cultural features like slag heaps from natural topographical features. This has led to the idea of testing other remote sensing methods in outfield archaeology, like airborne magnetometry.

Archaeology does not always have the resources to muster all available techniques that might benefit site detection. One theoretical study in Sweden considered the potential of using prospection and survey data that are normally used by the Swedish Transport Administration prior to road and railway development projects [111]. This study was more focused on the benefits of data sharing and providing guidance than on presenting new innovative techniques. Nevertheless, it made an important point through highlighting the potential of GIS platforms that are built for other purposes in providing specialized data for archaeologists.

In an ongoing case study at Gilbbesjávri in northernmost Finland, a combination of remote sensing materials has been employed to assess the state of 20th-century conflict heritage in the area [72]. Historical Second World War aerial photographs (taken by both the Finnish Air Forces and German Luftwaffe) have been employed alongside ALS-generated DEMs and other remote sensing products such as modern aerial imagery to gain a fuller understanding of the data. This approach has highlighted for example the large number of Second World War structures that have left no traces visible in the ALS data, owing to the wintertime conditions when they were constructed in snow and ice. Combinations of ALS-generated DEMs, aerial photographs, and radar data are being employed in this area in an ongoing project to develop semi-automated methods for the identification of Sami reindeer herding and hunting-related sites. So far, hundreds of previously unknown pitfall traps have been located from remote sensing data [112]. 


\subsection{Landscape Studies, Improved Landscape Understanding}

ALS provides a valuable opportunity for increased cultural-historical knowledge through allowing a better overview, but first and foremost it has the potential for contextualizing cultural heritage within a landscape's archaeological context. In landscape archaeology, the importance of analyzing the topographical and environmental contexts of cultural heritage in order to attain a stronger understanding of human-nature relations is emphasized. With a few exceptions, this potential was afforded little attention in the introductory phase of ALS's employment in archaeology, where emphasis was instead placed on the applicability of the method. This situation has changed considerably in recent years, as visual studies of ALS-generated elevation models are increasingly used to gain new knowledge based on novel discoveries across large landscape areas. This also includes enhanced knowledge on cultural heritage that has been known of and studied for a very long time and which can now be contextualized in a manner that was not previously possible. Studies that take advantage of this potential are now growing in number across the world [113-124]. A few studies involving ALS-generated DEMs or DTMs have been conducted with the purpose of reconstructing past landscapes $[125,126]$. Such environmental modellings are retrogressive and combine ALS data with other types of data from for instance drilling campaigns, archaeological excavations, or from outcrops. The resulting models are digital versions of the topography as it would have appeared in the past prior to changes induced by humans and/or natural processes

In a Norwegian study from 2013, the potential benefits of using ALS in landscape archaeology were discussed within a conceptual framework that considered archaeology as a key agent of landscape understanding [127]. The study focused on outfield archaeology and advocated recognition of the importance of all zones of the landscape in order to fully understand past human practice. This includes areas that today are perceived as natural areas despite extensive impacts from past human resource utilization. The paper stated that the biased survey coverage one finds in many countries-due to favoring cultivated landscapes at the expense of outfield areas-might affect our overall cultural historical understanding, specifically of how past human practice and society were organized. The study built on a case study area examining a thoroughly surveyed municipality situated in a forested valley in Norway. The study led to the assertion that the current cultural-historical understanding of this society must be modified significantly, especially after some major archaeological surveys were conducted that also covered large wooded areas omitted from previous survey campaigns.

ALS-generated 3D landscape models have also proved useful in visual archaeological landscape analyses where the aim was to reconstruct the past landscape expression as a basis for a field of view analysis: a so-called viewshed analysis or a similar approach to a visually-based landscape analysis. Visual field analyses have received considerable interest since the early 1990s by archaeologists using GIS in their work as an important approach to gain a better understanding of how people related to their surroundings in the past [128-130].

Risbøl et al. [131] carried out a GIS-based viewshed analysis along the coastline in Brunlanes in south-eastern Norway, focusing on Bronze Age burial cairns and their landscape contexts. An ALS data set constituted the basis for an examination of how detailed DEMs can help improve the foundation for visual landscape studies. The reasoning behind the study was that detailed DEMs have the potential to qualitatively improve representations of the past landscape. This includes the capacity to employ studies that entail a more detailed digital reproduction of paleo-landscapes, i.e., those that have been significantly affected by land elevation (uplifting of land). The study also incorporated past seaborne movements and served as an attempt to attain a better understanding of the location of burial cairns in the region. It indicated that the grave cairns were placed on the skyline in order to optimize their visibility to people approaching the area from the sea. 


\subsection{ALS from Drones}

Within the archaeological ALS domain, we have witnessed several improvements related to the instrumentation and more technical aspects of laser scanning. Within the archaeological community, considerable emphasis has been placed on developing visualization techniques in order to improve one's ability to interpret ALS-generated images [110]. The platforms used in airborne ALS have comprised either airplanes or helicopters and not much has changed in that sense. However, archaeologists engaged in remote sensing have increasingly exploited the possibilities offered by the rapidly growing development of unmanned aerial vehicles (UAVs), with drones providing new opportunities for further ALS development.

In July 2016, a test was carried out in Norway in which a wooded area holding a range of different archaeological features was scanned from a drone [132]. An area of $1.9 \mathrm{~km}^{2}$ was scanned with a Riegel VUX-LiDAR scanner mounted on a Camflight X8HL multirotor drone. The flight altitude was $120 \mathrm{~m}$.a.g. and the average ground point density 22 points $/ \mathrm{m}^{2}$. The results from the high-resolution drone scanning were compared with two data sets from previous ALS campaigns and related detection success studies. The results of the comparative study were presented in terms of the advantages and disadvantages of using drones instead of conventional platforms. The comparison also included an examination of the accuracy of recording the cultural features' physical properties.

Quite surprisingly, the study indicated only a slight improvement in detection success at a lower level than expected given the density of the ground points. This was explained with the assertion that very dense vegetation is impenetrable and obstructs laser beams from reaching all the way to the ground irrespective of the pulse frequency. By contrast, the documentation accuracy part of the study indicated more significant improvements. The advantages identified were related to flexibility, low flight altitude, and small laser footprint, together with the benefit of a far-reaching field of view. On the other hand, circumstances related to price, battery capacity, size of area, and the requirement of a line of sight between the drone operator and the drone were regarded as factors that might restrict drones' potential to be employed. Nevertheless, despite the mixed experiences of this first test, its conclusion was that ALS from a drone has the potential to bring archaeological remote sensing forward.

An important step in the use of Finnish archaeological ALS was taken in 2018, when the University of Helsinki deployed drone-based ALS of the Iron Age hillfort of Rapola in southern Finland. This was the first specifically archaeological ALS campaign in the country and the first instance of ALS mapping using a drone (the Riegl RiCopter with a VUX-1UAV sensor and Applanix AP20 IMU system). The research area of 9.5 ha was flown over four times in different directions, resulting in nearly 700 million points with a mean density of 7300 points $/ \mathrm{m}^{2}$ (varying from 3000 to 10,000 points $/ \mathrm{m}^{2}$ ). The absolute resolution of the DTM was approximately $2-3 \mathrm{~cm}$ [133]. The results were impressive in their detail and the improvement in mapping resolution was stark (Figure 11). For example, there were numerous small pit features visible in the DTM that had not been observed previously on the hillfort. Further field evaluation of the data is underway as part of a master's thesis project [134]. Another Finnish drone mapping campaign took place in autumn 2019 at the large multiperiod site Hartola Nuuttilanmäki 1-4 (Stone Age to historical period) as part of a doctoral research project at the University of Helsinki. The GeoDrone X4L and YellowScan Surveyor were used to map approximately $23 \mathrm{ha}$, resulting in clouds with over 68 million points [135]. Again, numerous features that had gone unnoticed in the field surveys were observed from the 0.1-m-resolution DTM generated. 

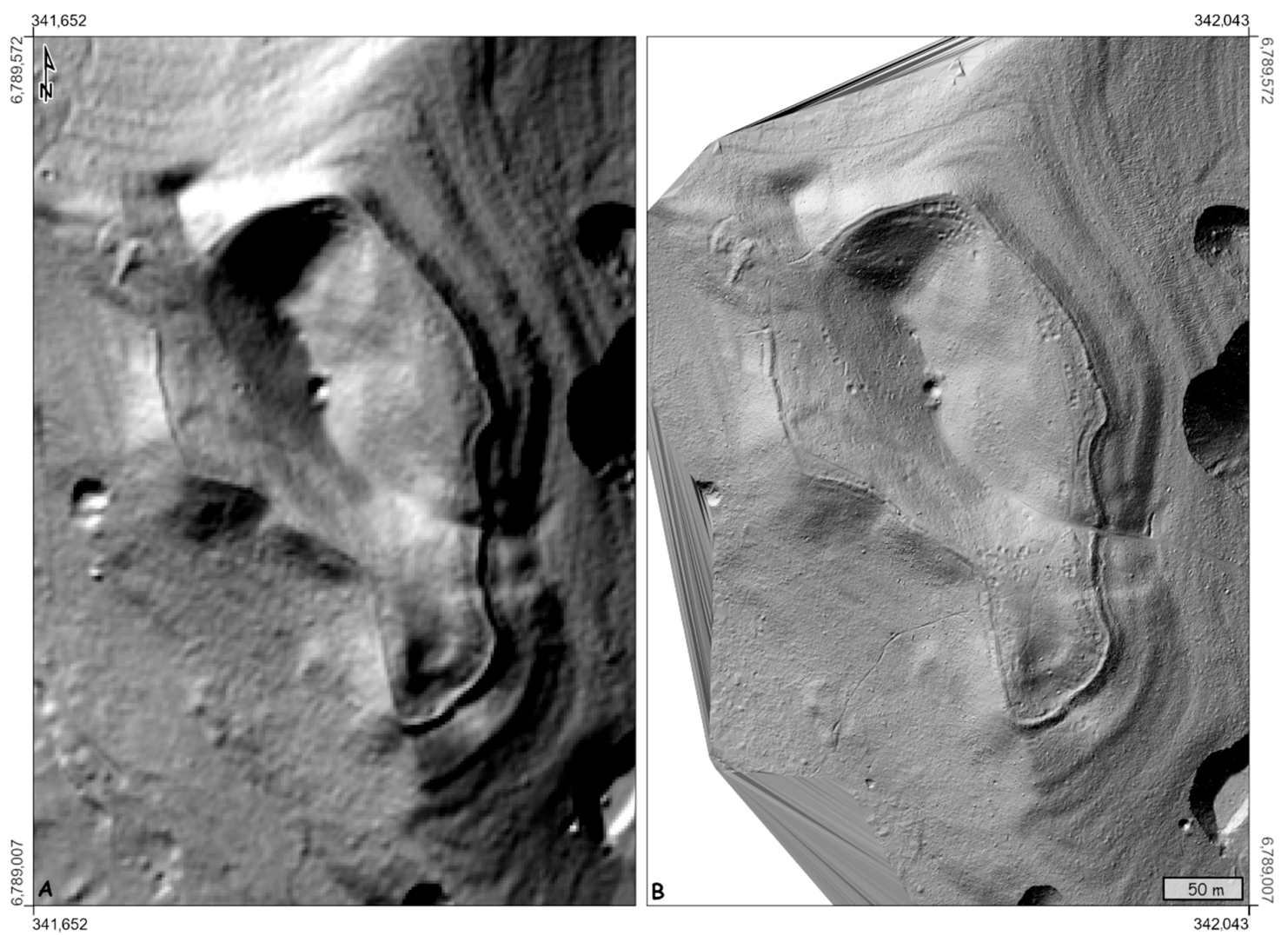

Figure 11. DTM of the Iron Age Rapola hillfort (Valkeakoski municipality) based on: (A) The open-access ALS data from the FNLS; (B) The University of Helsinki drone flight campaign (EPSG:3879 ETRS89/GK25FIN). (Illustration: Wesa Perttola and Oula Seitsonen).

\subsection{ALS and Community Archaeology/Local Engagement}

There are growing expectations among the greater society with respect to user participation, social engagement, and making public material more available through digitization. Authority is being challenged and dialogue with lay people as well as local involvement and participation have become increasingly common. This has also influenced archaeology, where local engagement is labelled as community archaeology, citizen science, and so forth.

An ongoing project was launched by the Norwegian University of Science and Technology (NTNU) University Museum in Trondheim in Norway in 2018, in which archaeologists collaborate with locals to construct an improved inventory of cultural features and monuments in outfield areas of the municipality of Klæbu [136]. The project was organized in such a way that archaeologists interpret ALS-generated DTMs for anomalies that are believed to be traces of past human activity. Lay people engaged in history-primarily members of the local historical society-are provided with registration forms, maps with marked anomalies, and more, with the mission of field verification of the anomalies. Prior to fieldwork, they are given a brief introduction to cultural heritage registration, before heading out to look up the anomalies on their own. Field checks are a time-consuming part of using ALS for the purpose of mapping cultural heritage. The idea behind the project is partly to receive assistance with the ALS-applied surveys and partly to create local engagement in outfield archaeology. In short, the main purpose of the initiative is to improve the content of the national cultural heritage database as well as to promote the cultural-historical significance of outfield and outfield resources in a long-term perspective. The introduction of ALS to the general public has also led to a situation where lay persons in Klæbu have started to engage with the publicly available ALS data.

In Finland, owing to the open access of ALS-generated DEMs, lay persons interested in history and archaeology have also become keen to explore the online visualizations available. This has developed 
into fruitful cooperation between archaeologists and history enthusiasts, who have spotted hundreds of previously unknown archaeological features that archaeologists have since confirmed, ranging from Stone Age house pits to traces of 20th-century conflicts [137]. In particular, Finnish war history enthusiasts have used ALS data widely as a guide for locating Second World War sites related to the Nazi German presence in Lapland (as an ally in 1940-1944 and as an enemy in 1944-1945). This collaboration has resulted in thousands of documented wartime structures around Rovaniemi-the capital of Lapland [138] — and at the main German defensive line of Sturmbock-Stellung in Eanodat [139].

In Denmark, the national DEM has received substantial attention from numerous hobby metal detectorists. Just like professional archaeologists, hobby detectorists use the hillshade as a source for locating potential new find spots. In general, this is positive since cooperation between archaeological authorities and metal detectorists is well developed. The activity can be observed in discussions on social media such as Facebook. This is also true of the Norwegian hobby detectorist community [140].

In Sweden, public interest in archaeological and historical sites and landscapes visible via ALS can be discerned on social media, mainly among people with an interest in cultural heritage, archaeology, history, or cultural geography. Many of the images posted are screenshots of national data in public map services, perhaps beyond the legal framework of rights associated with the data. Nevertheless, such posts seem to receive positive attention and occasionally stimulate constructive discussions regarding interpretation.

At present, as part of the Finnish Gilbbesjávri project, an online user interface is being developed for public engagement in identifying and mapping sites from ALS visualizations at the Zooniverse.org platform (Adler Planetarium, Chicago, U.S. and Oxford University, UK). This has been initiated based on previous positive experiences with the public participatory GIS crowdsourcing of cultural heritage sites [141] as well as the belief that using ALS DEMs as background maps could open up new public perspectives in the future. Like in Denmark and Norway, Finnish metal detectorists have also found that ALS data visualizations provide an excellent guide for determining potential metal-detecting localities. These individuals seem to discuss the advantages and hindrances of hillshades provided by the FNLS in their closed discussion forums and Facebook groups. In 2018, one programmer-metal detectorist developed an open-access desktop program for the 3D visualization of FNLS ASCII grid files and the reconstruction of past water levels, stating, "[i]n other words, you can for example land on a hillfort and see how the landscape looked 1000 years ago" (authors' translation) [142]. This program has proved popular among metal detectorists and the programmer is constantly developing it further. In the most recent version (3D Rinnevarjo_v1.2.0, open-access software by MacGyver, Finland), he has included a small program to transform the FNLS aerial photos from jp2 to bmp format (JP2toBMP) to drape them faster over the 3D hillshade visualizations generated in the program (Figure 12). A user can control various variables, such as the direction of the light, the vertical exaggeration, the water level (above sea level), and the opacity of the aerial images. Some archaeologists have also adopted this program as part of their simple and quick ALS 3D-visualization toolkit. 

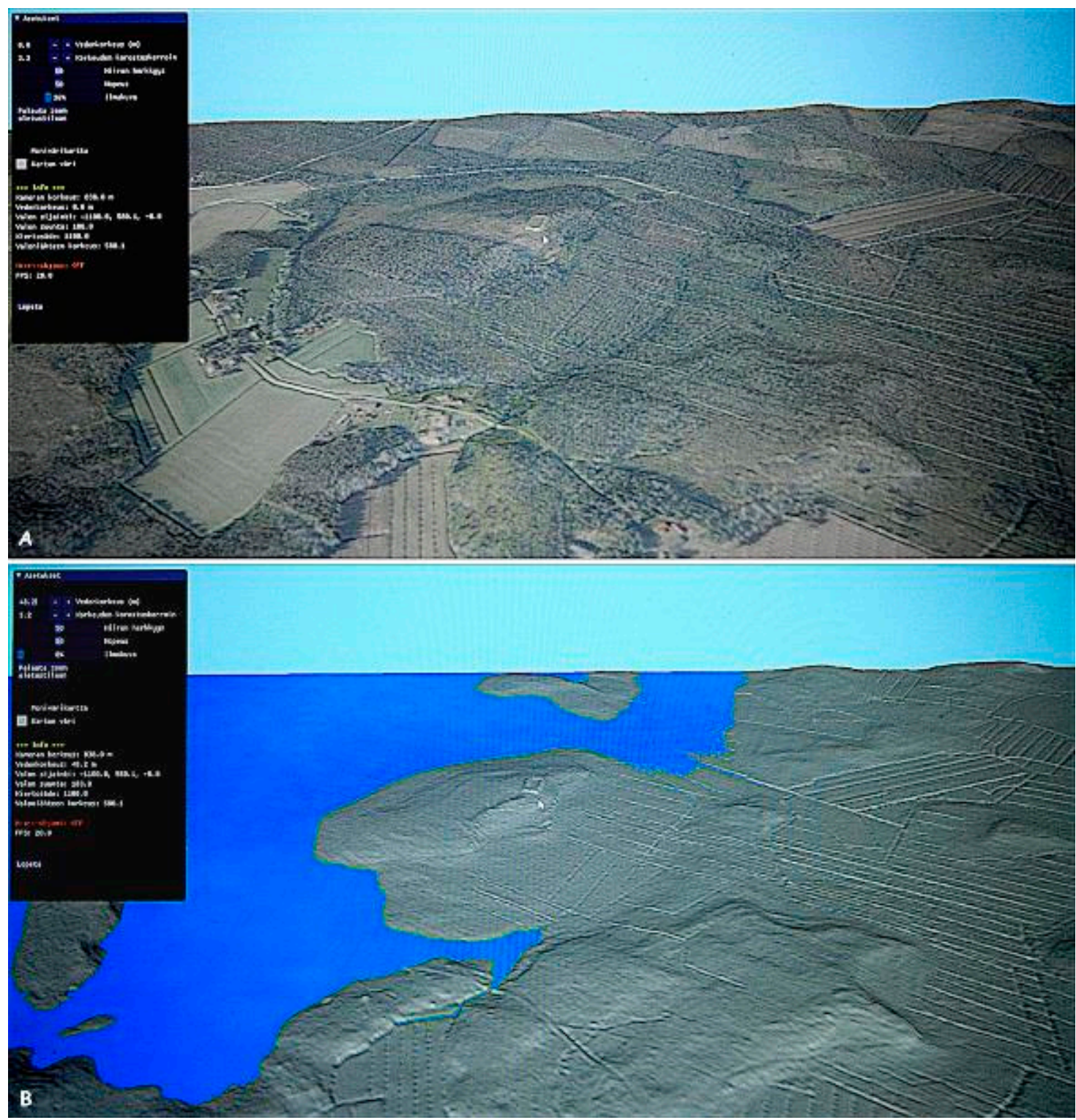

Figure 12. Screenshots of the Finnish metal-detecting hobbyists' freeware program [142] for three dimension (3D) visualization of ALS data and aerial photographs. (A) Aerial photograph draped over an ALS DEM, with the Neolithic Kastelli "Giant's Church" structure and housepits in the middle next to the cursor (see Figure 7); (B) Past water level reconstruction of the same scene (Illustration: Oula Seitsonen).

\section{Discussion}

As noted in this literature review, most research and development contributions to ALS's employment in archaeology from the Fenno-Scandinavian region can be related to objectives with a firm footing in mapping archaeology. The mere identification and listing of cultural features by means of ALS has clearly been the focus. This involves the statistical analysis of detection success, including the impacts of scanning parameters and the physical appearance of the cultural features targeted. This is in accordance with how ALS has been adopted by remote sensing archaeologists in many regions across the world. Mapping of archaeology in forested environments was a common use of ALS data from the outset, where a range of different features and monuments were identified, including field systems $[15,143,144]$ or hillforts and burial mounds [5,145-147]. Like in the Fenno-Scandinavian region, the ALS-based identification of features coming from the utilization of outfield resources like wood for charcoal burning, hunting and catching game, producing iron and tar etc. is also quite 
widespread elsewhere $[15,17,18,148]$. This is especially evident if we also include mapping of mining landscapes $[16,118,149,150]$. Field verification of identified anomalies is common, and use of results for statistical analysis in Fenno-Scandinavian projects has its international parallels [16,17,123,150-152]. Thus, in the Fenno-Scandinavian region, ALS employment with the purpose of mapping cultural features was to some extent initiated at an early stage soon after ALS emerged as a possibility in archaeology. Otherwise the uses form part of common trends regarding ALS.

The potential for applying semi-automated detection approaches to the interpretation of ALS data has received considerable attention in the North, especially from the Norwegian Computing Centre. This has been pioneering work, and the achievements have laid the foundation for similar studies in other regions outside the Fenno-Scandinavian region [153-155]. This has recently been advanced further by the employment of deep neural networks and machine learning [86,89-91].

Basically, the emphasis on ALS's use for mapping purposes can be related to the poor quality of recordings of vast forested areas. Even in Denmark, where most land is cultivated, ALS has mainly been used to map archaeology in forests and plantations. In addition to making a quantitative improvement to national cultural heritage databases, the quality of previous entries has improved, i.e., the georeferencing of earlier mappings. The interpretation of ALS-generated DTMs often involves the application of various visualization methods and in many cases ALS is used in combination with other data types, such as aerial photos and historical maps.

In addition to mapping, a few studies have been conducted related to the use of ALS for monitoring purposes. This means investigating how ALS data may be able to support cultural heritage management in its endeavor to monitor the state of cultural heritage sites and environments. It also includes preventing or mitigating the effects of unwanted incidents with negative or even illegal impacts on protected heritage. Projects testing the potential of ALS-based monitoring have been undertaken in outfield areas as well as on agricultural land. Still, we have not seen systematic use of ALS-generated terrain models in monitoring projects carried out by those administrative authorities with the responsibility for managing cultural heritage. While the use of other remote sensing techniques like satellite and aerial photos for monitoring purposes is rather widespread, the use of ALS for this purpose is also limited in other parts of the world. Yet, there are a few exceptions, mainly focusing on problems connected with erosion [156-158].

So far, the use of ALS in making substantial improvements to actual cultural-historical knowledge remains rather limited. The extensive ALS mapping of entire landscapes and consequently its potential to bring to light new knowledge about human practices in the past is an untapped resource that deserves more attention. ALS offers considerable potential for landscape archaeological studies when the conditions are right. Fragments of prehistoric landscapes occasionally show coherent patterns over larger areas, such as the scattered early Iron Age landscapes on Gotland briefly described above. Only a few Fenno-Scandinavian studies have addressed this potential, which is now being triggered across the world. This is a field with a high potential for improvement in the North. There is reason to believe that archaeological communities in the Fenno-Scandinavian region soon will be inspired to follow this trail as knowledge is attained about successful achievements in other parts of the world. Based on ALS campaigns, archaeologists in many regions across the globe have gradually obtained substantial increased knowledge regarding how people interacted with their surroundings in the past [113-124,159-163]. This also pertains to the potential that lies in digital reconstructions of past landscapes based on the use of ALS data $[125,126,164]$.

The potential for using ALS intensity data has not been pursued by archaeologists in the Fenno-Scandinavian region. ALS intensity data is (quote) "a secondary output of topographic measurements that records a laser 'image' of the land surface derived from measurements of the amplitude of each reflected laser pulse" (p. 1, [165]). When ALS scanning is performed, information about the intensity and reflectivity of the returned laser pulses is collected. These data hold information about conditions on the ground because the intensity and reflectivity of the returned pulses varies with the character of the surface they are returned from. Some projects have used intensity data with 
success, especially within geoarchaeology [165-167], but in general the potential of this secondary output is not well explored by archaeologists engaged with ALS.

The employment of ALS in water for archaeological purposes is so far limited, and no tests have been executed in Fenno-Scandinavia. Some attempts have been made to use bathymetric scanning for marine archaeological purposes in other parts of the world with relatively good results [168-170], and the potential for further development of this technology and methodology is clear. Scanning in water is done with laser light that is in the green spectrum and is therefore called green laser. Typically, depth data is collected in the sea using multi-jet echo sounder from a boat, but for sea areas where the depth is less than five meters, this technology is difficult to use, and green laser may be an alternative. The green laser pulses are sent to the water surface from an aircraft, penetrate through the water crust, and are reflected from the seabed from growths in the water or from structures lying on the seabed, such as shipwrecks and the like. It is a challenge that the laser pulses are exposed to light refraction, scattering, and/or absorption in contact with water, which limits the permeability. This makes bathymetric scanning best suited for low water near the coast as well as in shallow rivers and lakes. In clear water, the penetration depth can be up to $10 \mathrm{~m}$, but is usually less due to the presence of algae and other impurities as well as water disturbances. The demanding conditions in terms of visibility and weather conditions probably restrain the widespread use of bathymetric scanning in archaeology in the North also.

During the last 15 years, ALS has gained a firm foothold in Fenno-Scandinavian archaeology, and various questions regarding its application have been studied from different perspectives. Our predictions for ALS use, research, and development in our region mainly comprise the continued development of some of the themes that have already been considered. This applies to monitoring, for which ALS offers considerable potential for an increasingly efficient and reliable methodological approach. Mapping and monitoring cultural remains, monuments, sites, and landscapes as part of the overall environment is becoming increasingly important given climate change and there is reason to believe that this field of study will gain greater attention in the years to come. A limitation is that monitoring in some cases would demand scanning at recurrent intervals, preferably at the national scale if the site to be monitored is not predefined or known in advance. Follow-up studies concerning for example cemeteries or graves on the edge of sand quarries subjected to illegal quarrying would benefit from such scans. Where there is a lack of recurring ALS data, orthographs or satellite imagery with a higher spatial resolution may complement and assist in interpretation. Hopefully large-scale ALS will be undertaken with greater frequency in the future, additionally providing a historical record of the topographic and landscape changes occurring in our time. Experiences related to monitoring can be gained from the nature management sector, where ALS-based monitoring of the consequences of climate change has been performed, especially regarding coastal erosion and wear and tear of terrain [171-174].

In recent years, public participation has emerged as an increasingly pertinent principle in wider society. Involving the general public in all kinds of authority-led and research-led activities is gaining importance and we have already seen that ALS plays a role in this respect, with some examples already mentioned. Outside the Fenno-Scandinavian region, such projects have been underway for a while now, where lay people engage with experts in ALS work either by contributing to field verifications or via web-based interpretations of DEMs $[86,175,176]$. This is a trend that will certainly continue. One means of facilitating the use of ALS data and its more advanced visualizations in future could be to develop web services based on open-access data, with ready-made automated algorithms for different kinds of analyses that users can easily select for visualization.

Other areas that are currently under development are machine learning and AI. Studies involving the semi-automatic detection of archaeology based on AI principles are already being conducted, and in the years to come we expect further progress within this field of research.

Drones have spread like wildfire and their general use is extremely multifaceted. Within the ALS domain they represent a new platform, possibly owing to their increased payload capacity. Drones offer 
flexible use, are convenient for mapping small areas from low altitudes, and provide the user with the opportunity to be independent from commissioning ALS campaigns from companies. ALS from drones might also contribute via improved possibilities to cover vertical and sloping surfaces. In addition to the Norwegian ALS from the drone project discussed above, few ALS studies based on drone technology have been carried out at all so far $[177,178]$, but there is reason to expect that this will be a growing field of study in the future.

In the pioneering stages of ALS's introduction in archaeology, the possibilities for using this new method for thorough analyses with the purpose of increasing cultural-historical understanding were almost completely absent. ALS studies were almost exclusively focused on technical aspects as well as the ability to identify cultural features on the ground from above. This has changed dramatically in recent years, as today ALS projects conducted across the world are becoming important components of archaeological analyses, leading to substantial enhancements in knowledge concerning interactions between people and their environments in the past. With a few exceptions, this way of using ALS data has received little attention among archaeologists in the Fenno-Scandinavian area, but it is expected that this will change in the near future. For instance the above-mentioned Finnish project with the purpose of mapping war remains, military trenches, and battle fields is related to certain branch of landscape studies named conflict archaeology. This seems to have gained increased interest lately, and there are some additional examples of use of ALS data with the purpose of mapping wartime remains $[179,180]$.

What has not been mentioned in the review section is perhaps the most common utilization of ALS data: the use of ALS-generated DEMs as background maps when presenting and disseminating archaeology information and landscapes. This has become a rather common means of visually contextualizing archaeology, especially in reports, through for example illustrating ancient coastlines or presenting archaeological excavation sites in a topographical context. This type of use of ALS data could be expected to increase in the future, not least thanks to the growing use of drones and 3D applications within archaeology as well as the expected growth in the accessibility of high-resolution data.

\section{Conclusions}

The bulk of Fenno-Scandinavian research and development projects on ALS use in archaeology is somehow related to the sphere of cultural heritage management and to a lesser extent to the enhancement of knowledge about human practices in the past. Thus, the impacts of ALS on archaeological practice are more related to solving challenges within cultural heritage management than advancing what we might regard as actual archaeological research and cultural historical understanding. This is to some extent in contrast with ALS use in many other regions across the globe, and it is anticipated that future employment of ALS in Fenno-Scandinavia will increasingly include the potential to enhance cultural-historical understanding. Other knowledge gaps, like utilizing ALS intensity data and bathymetrical laser scanning, have been identified but it remains unclear if these aspects will be pursued in the near future by archaeologists in the North.

The aptitude of ALS in monitoring campaigns has been proved through various studies, but actual ALS-based surveillance in cultural heritage management is still to come. Lay people's engagement with ALS is increasing, sometimes initiated by archaeologists and sometimes by locals themselves. It seems that the interested public — such as local historians and metal detectorists-are increasingly using freely available ALS data for various purposes. Finally, we expect that ALS using drones will be an expanding field of research and development in the coming years. As in many other places across the world, ALS has been adopted by Fenno-Scandinavian archaeology, which has in turn contributed to its research and development. The means and extent have been assessed in this review.

Author Contributions: Conceptualization, O.R.; Methodology, all authors; Investigation, all authors; Writing-Original Draft Preparation, O.R.; Writing-Review \& Editing, all authors; Visualization, all authors; Supervision, O.R.; Project Administration, O.R. All authors have read and agreed to the published version of the manuscript. 
Funding: Seitsonen was funded by project Domestication in Action (Academy of Finland grant number 308322 and European Research Council grant number 2017 756431).

Conflicts of Interest: The authors declare no conflict of interest.

\section{References}

1. Holden, N. Digital airborne remote sensing: The principles of LiDAR and CASI. AARGNews 2001, 22, 23.

2. Motkin, D. An assessment of LIDAR for archaeological use. AARGNews 2001, 22, 24-25.

3. Shell, C.; Roughley, C. Exploring the Loughcrew landscape: A new approach with airborne lidar. Archaeol. Irel. 2004, 18, 22-25.

4. Bewley, R.H.; Crutchley, S.P.; Shell, C.A. New light on an ancient landscape: Lidar survey in the Stonehenge World Heritage Site. Antiquity 2005, 79, 636-647. [CrossRef]

5. Bofinger, J.; Kurz, S.; Schmidt, S. Ancient maps-Modern data sets: Different investigative techniques in the landscape of the Early Iron Age princely hill fort Heuneburg, Baden-Württemberg. In From Space to Place: 2nd International Conference on Remote Sensing in Archaeology; Campana, S., Forte, M., Eds.; British Archeological Review; Archaeopress: Oxford, UK, 2006; Volume 1568, pp. 87-92.

6. Risbøl, O.; Gjertsen, A.K.; Skare, K. Airborne laser scanning of cultural remains in forests-Some preliminary results from a Norwegian project. In From Space to Place: 2nd International Conference on Remote Sensing in Archaeology; Campana, S., Forte, M., Eds.; British Archaeological Review; Archaeopress: Oxford, UK, 2006; Volume 1568, pp. 107-112.

7. Clemmensen, N.C. 2010 DHM-den digitale højdemodel—Reliefkortet. In Oldtidsagre i Danmark, Sjælland, Møn og Lolland-Falster; Nielsen, V., Ed.; Jysk Arkæologisk Selskab, Aarhus Universitetsforlag: Aarhus, Denmark, 2010; pp. 25-27, ISBN 9788788415643.

8. Nielsen, V. (Ed.) Oldtidsagre i Danmark—Sjælland, Møn og Lolland-Falster; Jysk Arkæologisk Selskabs Skrifter, Aarhus University Press: Århus, Denmark, 2010.

9. Clemmensen, N.C. 2012 Landskabslæsning. Skalk 2012, 3, $24-27$.

10. Alexander, B.; Jansson, J.; Söderman, U. Laserskanning Från Flyg Och Fornlämningar i Skog; Rapport 2009:09; Kulturmiljöenheten. Länsstyrelsen Dalarnas län: Falun, Sweden, 2009.

11. Kurri, I.; Haimila, M. Metsää syvemmältä_Lidar-aineisto arkeologian apuvälineenä. Muinaistutkija 2010, 1, 63-68.

12. Seitsonen, O. Juoksuhautoja ja asumuspainanteita: Kokemuksia lidarlaserkeilausaineiston käytöstä kenttäarkeologiassa. Muinaistutkija 2011, 2, 36-44.

13. Doneus, M.; Briese, C.; Fera, M.; Janner, M. Archaeological prospection of forested areas using full-waveform airborne laser scanning. J. Archaeol. Sci. 2008, 35, 882-893. [CrossRef]

14. Doneus, M.; Briese, C. Airborne laser scanning in forested areas-Potential and limitations of an archaeological prospection technique. In Remote Sensing for Archaeological Heritage Management; Cowley, D.C., Ed.; EAC Occasional Paper No. 5; Europae Archaeologia Consilium (EAC): Brussels, Belgium, 2011; pp. 59-76.

15. Devereux, B.J.; Amable, G.S.; Crow, P.; Cliff, A.D. The potential of airborne lidar for detection of archaeological features under woodland canopies. Antiquity 2005, 79, 648-660. [CrossRef]

16. Gallagher, J.M.; Josephs, R.L. Using LiDAR to detect cultural resources in a forested environment: An example from Isle Royale National Park, Michigan, USA. Archaeol. Prospect. 2008, 15, 187-206. [CrossRef]

17. Johnson, K.M.; Ouimet, W.B. Rediscovering the lost archaeological landscape of southern New England using airborne light detection and ranging (LiDAR). J. Archaeol. Sci. 2014, 43, 9-20. [CrossRef]

18. Georges-Leroy, M. Airborne Laser Scanning for the management of archaeological sites in Lorraine (France). In Remote Sensing for Archaeological Heritage Management; Cowley, D.C., Ed.; EAC Occasional Paper No. 5; Europae Archaeologia Consilium (EAC): Brussels, Belgium, 2011; pp. 229-234.

19. Riksantikvarieämbetet \& Skogsstyrelsen. Redovisning Av 2016 Års Arbete Inom Projektet Kvalitetssäkring Skog Och Historia. URL 2020-01-16. 2016. Available online: https://www.raa.se/app/uploads/2017/06/2016_ SH_rapport_inklBilagor.pdf (accessed on 16 January 2020).

20. Norwegian Mapping Authority. Available online: https://kartverket.no/Prosjekter/Nasjonal-detaljerthoydemodell/ (accessed on 8 January 2020).

21. Norwegian Mapping Authority. Available online: https://hoydedata.no/LaserInnsyn/ (accessed on 8 January 2020). 
22. Grubbmo, E.; Andersen, O.; Hagen, I.; Gaarud, J.E. Samfunnsøkonomisk Analyse Av Nasjonal Detaljert Høydemodell. Rapport til Kartverket. Available online: https://kartverket.no/globalassets/arkiv/kart/ nasjonal-hoydemodell/rapport---samfunnsokonomisk-analyse-nasjonal-detaljert-hoydemodell.pdf (accessed on 10 December 2019).

23. SDFE/Styrelsen for Dataforsyning og Effektivisering. December 2009, Oktober 2014: Produktspecifikation Danmarks Højdemodel DHM-2007/Terræn; Miljøministeriet, Kort \& Matrikelstyrelsen: København, Denmark, 2014.

24. Clemmensen, N.C. Fra laser til landkort. Arkæologisk Forum 2010, 23, 27-30.

25. SDFE/Styrelsen for Dataforsyning og Effektivisering. 2016: Produktspecifikation Danmarks Højdemodel DHM/Terræn; Miljøministeriet, Kort \& Matrikelstyrelsen: København, Denmark, 2016.

26. Danish Geodata Agency. Available online: www.sdfkort.dk/spatialmap (accessed on 30 November 2019).

27. Lantmäteriet. Nationell Höjdmodell, Produktionsstatus. Available online: https://www.lantmateriet.se/ External/geolex/bild_hojd/utfall/utfall_nh.pdf (accessed on 27 April 2020).

28. Lantmäteriet. Produktbeskrivning: Höjdmodell Visning. Dokumentversion 1.4; 2019. Available online: https://www.lantmateriet.se/globalassets/kartor-och-geografisk-information/geodatatjanster/pb_hojd_ visn_v1.1.0_1.4.pdf (accessed on 26 January 2020).

29. Lantmäteriet: Produktbeskrivning: Höjdmodell Nedladdning. Dokumentversion 1.4. Available online: https://www.lantmateriet.se/globalassets/kartor-och-geografisk-information/geodatatjanster/hojdmodell_ nedladdning_v1.0_1.4.pdf (accessed on 26 January 2020).

30. Riksantikvarieämbetet, Fornsök. Available online: https://www.raa.se/hitta-information/fornsok/ (accessed on 27 April 2020).

31. Lantmäteriet. Product Description: Laser data-Laserdata Skog. Document Version 1.2. 2019-10-01. Available online: https://www.lantmateriet.se/globalassets/kartor-och-geografisk-information/hojddata/ lidar_data_skog.pdf (accessed on 26 January 2020).

32. Finnish National Land Service. Available online: https://iedostopalvelu.maanmittauslaitos.fi/tp/kartta (accessed on 24 December 2019).

33. Statistics Norway. Available online: https://www.ssb.no/en/ (accessed on 28 January 2020).

34. Nielsen, V.; Clemmensen, N.C. (Eds.) Oldtidsagre i Danmark, Fyn og Langeland; Jysk Arkæologisk Selskab, Aarhus University Press: Århus, Denmark, 2015.

35. Levin, G.; Normander, B. Arealanvendelse i Danmark Siden Slutningen af 1800-Tallet. Faglig Rapport fra DMU $n r$. 682; Danmarks Miljøundersøgelser. Aarhus Universitet: Aarhus, Denmark, 2008; ISBN 978-87-7073-059-4.

36. Olesen, L.H.; Mauritsen, E.S. Skjulte Fortidslandskaber i Skov og Hede Afsløres Med Detaljerede Laserscanninger. Holstebro Museums Årsskrift 2012, 24-40.

37. Fund \& Fortidsminder. Available online: http://www.kulturarv.dk/fundogfortidsminder/ (accessed on 30 November 2019).

38. Klinkby, K.J.; Klingenberg, M.; Henningsen, H. Fredede Fortidsminder i Midt- og Vestjylland. Resultaterne affem års Tilsyn; Holstebro Museum: Holstebro, Denmark, 2014.

39. Statistics Sweden. Land Use in Sweden, 7th ed.; Markanvändningen i Sverige, sjunde utgåvan; SCB, Statistiska Centralbyrån Bibliotek: Stockholm, Sweden, 2019.

40. Framstad, E.; Berglund, H.; Gundersen, V.; Heikkilä, R.; Lankinen, N.; Peltola, T.; Risbøl, O.; Weih, M. Increased Biomass Harvesting for Bioenergy: Effects on Biodiversity, Landscape Amenities and Cultural Heritage Values; Framstad, E., Ed.; TemaNord, Nordic Council of Ministers: Copenhagen, Denmark, 2009; Volume 591, pp. 1-161, ISBN 978-92-893-1962-1.

41. Statistics Finland. Available online: https://www.stat.fi/index_en.html (accessed on 7 January 2020).

42. Seitsonen, O.; Moshenska, G. Who owns the 'wilderness'? Indigenous Second World War landscapes in Sápmi, Finnish Lapland. In Conflict Landscapes: Materiality and Meaning in Contested Places; Saunders, N.J., Cornish, P., Eds.; Routledge: Abingdon, UK, 2020.

43. Seitsonen, O. Archaeologies and Heritage of Hitler's Arctic War: Second World War German Material Legacy in Finnish Lapland; Routledge: Abingdon, UK, 2020.

44. Risbøl, O. Airborne laser scanning of cultural features in Norwegian forests-Preliminary results from a pilot project. In Past from the Air: Aerial Archaeology and Landscape Studies in Northern Europe. Papers from the International Seminar Held at Klaipéda University, 16-20 November 2005; Department of Cultural Heritage Protection, Klaipéda University: Klaipėda, Lithuania, 2007; pp. 57-70. 
45. Risbøl, O. Neglected cultural heritage in Norwegian forests-State of affairs, challenges and solutions. In Archaeological Sites in Forests: Strategies for their Protection; Irlinger, W., Suhr, G., Eds.; Volk Verlag: Munich, Germany, 2017; Volume 14, pp. 25-31.

46. Holmsen, A. Eidsvoll Bygds Historie: Bygdehistorien til Omkring 1700; bind I, 1. del; Eidsvoll Bygdebokkomité: Oslo, Norway, 1961.

47. Holmsen, A. Eidsvoll Bygds Historie: Bygdehistorien 1700-1914; bind I, 2. del; Eidsvoll Bygdebokkomité: Oslo, Norway, 1961.

48. Risbøl, O. Fugleperspektiv på kulturminner: Bruk av flybåren laserskanning i arkeologien. Viking Nor. Arkeol. Årbok 2009, 72, 211-226.

49. Skare, K. Som lys fra oven. En introduksjon til flybåren laserskanning. Primit. Tider Arkeol. Tidsskr. 2011, 13, 101-112.

50. Pilø, L. Opptakt_FoU Delprosjekt: Utredning Av Egnethet Av HD-Lidarkartlegging Som Arbeidsverktøy I Kulturminneforvaltningen; Kulturhistoriske skrifter 2013/1; Oppland Fylkeskommun: Lillehammer, Norway, 2013; pp. 1-51.

51. Risbøl, O. Towards an improved archaeological record through the use of airborne laser scanning. In Space, Time and Place. 3rd International Conference on Remote Sensing in Archaeology; Forte, M., Campana, S., Liuzza, C., Eds.; British Archaeological Review: Oxford, UK, 2010; Volume 2118, pp. 105-112.

52. Nesbakken, A.; Risbøl, O. Med laserblikk på villreinfangst i Varanger. OTTAR 2011, 2, 41-47.

53. Bollandsås, O.M.; Risbøl, O.; Ene, L.T.; Nesbakken, A.; Gobakken, T.; Næsset, E. Using airborne small-footprint laser scanner data for detection of cultural remains in forests: An experimental study of the effects of pulse density and DTM smoothing. J. Archaeol. Sci. 2012, 39, 2733-2743. [CrossRef]

54. Risbøl, O.; Gustavsen, L. Håndbok. Bruk av luftbåren laserskanning (lidar) i arkeologien. Riksantikvaren 2016, 1-61. [CrossRef]

55. Risbøl, O.; Gjertsen, A.K.; Skare, K. Flybåren laserskanning og kulturminner i skog: Ny teknologi i arkeologiens tjeneste. Kart og Plan 2007, 2, 78-90.

56. Risbøl, O.; Bollandsås, O.M.; Nesbakken, A.; Ørka, H.O.; Næsset, E.; Gobakken, T. Interpreting cultural remains in airborne laser scanning generated digital terrain models: Effects of size and shape on detection success rates. J. Archaeol. Sci. 2013, 40, 4688-4700. [CrossRef]

57. Olesen, L.H.; Mauritsen, E.S.; Broch, M. Luftfotoarkæologi 2. Luftfotos, Droner, Laser $\mathcal{E}$ Geofysik; De Kuturhistoriske Museer i Holstebro Kommune: Holstebro, Denmark, 2019.

58. Olesen, L.H.; Mauritsen, E.S. Luftfotoarkæologi i Danmark; Holstebro Museum: Holstebro, Denmark, 2015.

59. Lindegaard, M.R. Danmarks Oldtid i Landskabet; Lindhardt og Ringhof; Slots- og Kulturstyrelsen: København, Denmark, 2019.

60. Stott, D.; Kristiansen, S.M.; Sindbæk, S.M. Searching viking age fortresses with automatic landscape classification and feature detection. Remote Sens. 2019, 11, 1881. [CrossRef]

61. Mohtashami, S.; Willén, E. Kartering av fornminnen i skogen med fjärranalys; Arbetsrapport från Skogforsk nr. 923-2017; Skogforsk: Uppsala, Sweden, 2017.

62. Skogens kulturarv i Kvarkenregionen2. Available online: http://www.skaik.eu/ (accessed on 31 December 2019).

63. Andersson, B. Skogens Kulturarv i Kvarkenregionen2-Verksamheter under 2011, Västerbottens län; Arkeologisk rapport dnr 622/09; Västerbottens Museum: Umeå, Sweden, 2012.

64. Olofsson, K.J. 2014 års Fornminnesinventering i Jämtlands län. Härjedalens Kommun; Rapport-Jamtli 2015:7.; Jamtli: Östersund, Sweden, 2015.

65. Ulfhielm, B.; Björck, M. Inventering i Skogs Socken: Skogs Socken, Söderhamns Kommun, Hälsingland, 2015. Rapport Länsmuseet Gävleborg; Länsmuseet Gävleborg: Gävle, Sweden, 2016.

66. Törnqvist, O.; Lindeberg, G. Fjärranalys för Kulturmiljövården: Underlag för Arbete Med Lägesbestämda Fornlämningar; Riksantikvarieämbetet och Metria: Stockholm, Sweden, 2014.

67. Törnqvist, O. Fjärranalys för Kulturmiljövården. Steg 2: Rekommenderade Derivatprodukter och Produktionsmetoder; Riksantikvarieämbetet och Metria: Stockholm, Sweden, 2015.

68. Norstedt, G.; Axelsson, A.L.; Laudon, H.; Östlund, L. Detecting cultural remains in boreal forests in Sweden using airborne laser scanning data of different resolutions. J. Field Archaeol. 2019, 1-13. [CrossRef]

69. Seitsonen, O. LiDAR-kaukokartoitusaineistojen visualisointi ja analysointi: Paikkatietoalgoritmeja arkeologeille. Muinaistutkija 2013, 1, 2-16. 
70. Koivisto, S.; Laulumaa, V. Pistepilvessä-Metsien arkeologiset kohteet LiDAR-ilmalaserkeilausaineistoissa. Arkeologipäivät 2012, 2013, 51-67.

71. Mustonen, R. Conquering the forests with lasers and social media-Finland's National Forest Programme 2015 Cultural Heritage Survey. In Archaeological Sites in Forests: Strategies for their Protection; Irlinger, W., Suhr, G., Eds.; Volk Verlag: Munich, Germany, 2017; Volume 14, pp. 19-24.

72. Stichelbaut, B.; Thomas, S.; Seitsonen, O.; Gheyle, W.; De Mulder, G.; Hemminki, V.; Plets, G. Operation Northern Light: Remote sensing of a Second World War conflict landscape in Northern Finland. In Conflict Landscapes: Materiality and Meaning in Contested Places; Saunders, N.J., Cornish, P., Eds.; Routledge: Abingdon, UK, 2020.

73. Gustavsen, L.; Paasche, K.; Risbøl, O. Arkeologiske Undersøkelser: En Vurdering av Nyere Avanserte Arkeologiske Registreringsmetoder i Forbindelse med Vegutbyggingsprosjekter; Vegdirektoratet: Oslo, Norway, 2013.

74. Alexander, B. Laserskanning och agrara lämningar. Agrarlämningar i det nutida samhället. Vad har gjorts och hur går vi vidare med undersökningar, värdering och handläggning av agrara lämningar. Rapport från seminariet $i$ Jönköping 17-18 April 2013; Engman, F., Lorenzon, M., Vestbö Franzén, Å., Eds.; Jönköpings Läns Museums Skriftserie: Jönköping, Sweden, 2015; pp. 77-93.

75. Carlsson, D. Ett Okänt Kulturlandskap Träder Fram. Laserkartan som Underlag för Att Registrera Fossil Åkermark; Dnr: 431-2659-2016, Region Gotland, Gotlands län. Arrendus rapport 2019:43; Arkeologisk utredning: Visby, Sweden, 2019.

76. Nord, J.; Nyqvist, R.; Sandberg, C. Skogens Antikvariskt Fördolda Kulturlandskap. Ett Projekt I Samverkan Mellan Länsstyrelsen I Hallands Län, Västra Götalands Län Samt Skogsstyrelsen. 2019. Available online: https://www.lansstyrelsen.se/download/18.26f506e0167c605d56955b0d/1552577574389/ 2019-7\%20Skogens\%20antikvariskt\%20f\%C3\%B6rdolda\%20kulturlandskap.pdf (accessed on 27 April 2020).

77. Risbøl, O. Kulturminner i skog - bruk av flybåren laserskanning som grunnlag for en bærekraftig forvaltning. In Kulturarv, Kulturminner og Kulturmiljøer. Presentasjoner fra NIKUs Strategiske Instituttprogrammer 2006-2010; Sætren, A., Fløisand, I., Swensen, G., Skar, B., Eds.; NIKU Tema 39; Norsk institutt for kulturminneforskning: Oslo, Norway, 2012; pp. 100-104.

78. Risbøl, O.; Nesbakken, A.; Ørnelund Nilsen, J.E. Hva skogen skjuler-Kulturminneregistreringer fra lufta. Skog 2012, 5, 26-28.

79. Tomter, S.; Risbøl, O. Kulturminner i skog. In Bærekraftig Skogbruk i Norge; Tomter, S.M., Dalen, L.S., Eds.; Norsk institutt for skog og landskap: Ås, Norway, 2014; pp. 230-233.

80. Risbøl, O.; Gjertsen, A.K.; Skare, K. Flybåren laserskanning og registrering av kulturminner i skog. Fase 3; NIKU Rapport 22; Norsk institutt for kulturminneforskning: Oslo, Norway, 2008.

81. Trier, Ø.D.; Pilø, L.H. Automatic detection of pit structures in airborne laser scanning data. Archaeol. Prospect. 2012, 19, 103-121. [CrossRef]

82. Trier, Ø.D.; Pilø, L.H. Archaeological mapping of large forested areas, using semi-automatic detection and visual interpretation of high-resolution LiDAR data. In CAA2014. 21st Century Archaeology: Concepts, Methods and Tools, Proceedings of the 42nd Annual Conference on Computer Applications and Quantitative Methods in Archaeology, Paris, France, 22-25 April 2014; Archaeopress: Oxford, UK, 2015; pp. 81-86.

83. Trier, $\varnothing, D . ;$ Zortea, M. Semi-automatic detection of cultural heritage in LiDAR data. In Proceedings of the 4th International Conference on Geographic Object-Based Image Analysis (GEOBIA), Rio de Janeiro, Brazil, 7-9 May 2012; pp. 1-6.

84. Trier, Ø.D.; Zortea, M.; Tonning, C. Automatic detection of mound structures in airborne laser scanning data. J. Archaeol. Sci. 2015, 2, 69-79. [CrossRef]

85. Trier, Ø.D.; Pilø, L.H.; Johansen, H.M. Semi-automatic mapping of cultural heritage from airborne laser scanning data. Sémata 2015, 27, 159-186.

86. Lambers, K.; Verschoof-van der Vaart, W.B.; Bourgeois, Q.P.J. Integrating remote sensing, machine learning, and citizen science in Dutch archaeological prospection. Remote Sens. 2019, 11, 794. [CrossRef]

87. LeCun, Y.; Bengio, Y.; Hinton, G. Deep learning. Nature 2015, 521, 436-444. [CrossRef]

88. Trier, Ø.D.; Salberg, A.B.; Pilø, L.H. Semi-automatic mapping of charcoal kilns from airborne laser scanning data using deep learning. In Oceans of Data, Proceedings of the 44st Annual Conference on Computer Applications and Quantitative Methods in Archaeology, Oslo, Norway, 29 March-2 April 2016; Uleberg, E., Matsumoto, M., Eds.; Archaeopress: Oxford, UK, 2018; pp. 221-231. 
89. Guyot, A.; Hubert-Moy, L.; Lorho, T. Detecting Neolithic burial mounds from LiDAR-derived elevation data using a multi-scale approach and machine learning techniques. Remote Sens. 2018, 10, 225. [CrossRef]

90. Trier, Ø.D.; Cowley, D.C.; Waldeland, A.U. Using deep neural networks on airborne laser scanning data: Results from a case study of semi-automatic mapping of archaeological topography on Arran, Scotland. Archaeol. Prospect. 2018, 26,1-11. [CrossRef]

91. Verschoof-van der Vaart, W.B.; Lambers, K. Learning to look at LiDAR. The use of R-CNN in the automated detection of archaeological objects in LiDAR data from The Netherlands. J. Comput. Appl. Archaeol. 2019, 2, 31-40. [CrossRef]

92. Kermit, M.; Reksten, J.H.; Trier, Ø.D. Towards a National Infrastructure for Semi-Automatic Mapping of Cultural Heritage in Norway. In Oceans of Data, Proceedings of the 44st Annual Conference on Computer Applications and Quantitative Methods in Archaeology, Oslo, Norway, 29 March-2 April 2016; Uleberg, E., Matsumoto, M., Eds.; Archaeopress: Oxford, UK, 2018; pp. 159-172.

93. Trier, Ø.D.; Reksten, J.H. Automated Detection of Cultural Heritage in Airborne Lidar Data. CultSearcher Operationalization; Report, SAMBA/50/19, 30 December 2019; Norsk Regnesentral/Norwegian Computing Center: Oslo, Norway, 2019.

94. Goodchild, H.; Holm, N.; Sindbæk, S. Borgring: The discovery of a Viking Age ring fortress. Antiq. Access 2017, 91, 1027-1042. [CrossRef]

95. Žutautas, V. Charcoal Kiln Detection from LiDAR-derived Digital Elevation Models Combining Morphometric Classification and Image Processing Techniques. Faculty of Engineering and Sustainable Development, IT and Land Management. Master's Thesis, Högskolan i Gävle, Gävle, Sweden, 2017.

96. Matos-Machado, R.; Toumazet, J.P.; Bergès, J.C.; Amat, J.P.; Arnaud-Fassetta, G.; Bétard, F.; Bilodeau, C.; Hupy, J.P.; Jacquemot, S. War landform mapping and classification on the Verdun battlefield (France) using airborne LiDAR and multivariate analysis. Earth Surf. Process. Landf. 2019, 44, 1430-1448. [CrossRef]

97. Barlindhaug, S.; Holm-Olsen, I.M.; Risan, T.; Risbøl, O.; Bøe Sollund, M.L. Fortiden sett fra lufta—Fjernmålingsmetoder til overvåking av kulturminner og kulturlandskap. Kart og Plan 2008, 2, 106-118.

98. Risbøl, O.; Amundsen, H.R. Tilstandsanalyse og miljøovervåking av kulturminner og—Miljøer langs regulerte vassdrag ved bruk av flybåren laserskanning. In Viking, Norsk arkeologisk årbok, Bind LXXIV; Norsk Arkeologisk Selskap: Oslo, Norway, 2011; pp. 279-304.

99. Nesbakken, A.; Risbøl, O. Strandgravfeltet på Mølen-Deteksjon av endringer gjennom 50 år. Kart og Plan 2014, 2, 134-149.

100. Risbøl, O.; Briese, C.; Doneus, M.; Nesbakken, A. Monitoring cultural heritage by comparing DEMs derived from historical aerial photographs and airborne laser scanning. J. Cult. Herit. 2015, 16, 202-209. [CrossRef]

101. Vennersdorf, M. Den lille (terræn-)forskel-Danmarks Højdemodel som kilde til erosion og slid på arkæologiske lokaliteter i dyrket mark. Arkæologisk Forum 2017, 37, 8-18.

102. Lindeberg, G. Riskinventering Med Stöd Av Nationell Höjdmodell-Sammanfattande rapport för Fyra Effektstudier av Havsnivåhöjningar och en Tillämpning vid Riskinventering av väg; Myndigheten för Samhällskydd och Beredskap (MSB): Stockholm, Sweden, 2014; Publication number: MSB625; ISBN 978-91-7383-398-1.

103. Lindeberg, G.; Larsson, K.; Hedhammar, E.; Carlsson, M. Rapport. Framtida Havsnivåhöjningar och Nationell Höjdmodell-Användning för Kulturmiljövården och Analys av Stigande Havsnivåers Inverkan på Fasta Fornlämningar och Kulturhistorisk Bebyggelse; Metria AB: Sockholm, Sweden, 2013.

104. Langhammer, D. Remote Sensing within Swedish Archeology. AARGnews 2016, 52, 60-70.

105. Risbøl, O.; Thuestad, A.E.; Barlindhaug, S.; Myrvoll, E.R. Remote sensing archaeology on the outskirts of Europe. In Sensing the Past: Contributions from the ArcLand Conference on Remote Sensing for Archaeology; Posluschny, A.G., Ed.; Habelt-Verlag: Bonn, Germany, 2015; pp. 68-69.

106. Vorren, Ø. Villreinfangst $i$ Varanger fram til 1600-1700-årene; Tromsø museums skrifter XXVIII; Nordkalott-Forlaget: Tromsø, Norway, 1998; ISBN1 8273801780, ISBN2 8271420275.

107. Zakšek, K.; Oštir, K.; Kokalj, Ž. Sky-View Factor as a Relief Visualization Technique. Remote Sens. 2011, 3 , 398-415. [CrossRef]

108. Stamnes, A.A.; RisbøL, O.; Stenvik, L.F. (Eds.) Investigating Early Iron Production by Modern Remote Sensing Technologies; The Royal Norwegian Society of Sciences and Letters: Trondheim, Norway, 2019; Volume 2, pp. 1-114. 
109. Risbøl, O.; Gustavsen, L. Mapping early iron production features in woodland using remote sensing techniques. In Investigating Early Iron Production by Modern Remote Sensing Technologies; Stamnes, A.A., Risbøl, O., Stenvik, L.F., Eds.; The Royal Norwegian Society of Sciences and Letters: Trondheim, Norway, 2019; Volume 2, pp. 35-56.

110. Kokalj, Z.; Hesse, R. Airborne Laser Scanning Raster Visualization: A Guide to Good Practice; Prostor kraj čas, 14; Založba ZRC: Ljubljana, Slovenia, 2017.

111. Buckland, P.; Nyqvist, R.; Alexander, B.; Palsson, G.; Ericsson, S. The Swedish Transport Administration's Toolbox and its Potential in Archaeological and Cultural Heritage Survey. Including a Brief Review of Remote Sensing, Prospection and Geodata Analysis Methods for Archaeology and Cultural Heritage; Environmental Archaeology Lab. Report no. 2018-001; Umeå universitet: Umeå, Sweden, 2018.

112. Domestication in Action. Available online: https://domesticationinaction.wordpress.com/ (accessed on 22 December 2019).

113. Chase, A.F.; Chase, D.Z.; Fisher, C.T.; Leisz, S.J.; Weishampel, J.F. Geospatial revolution and remote sensing LiDAR in Mesoamerican archaeology. Proc. Natl. Acad. Sci. USA 2012, 109, 12916-12921. [CrossRef] [PubMed]

114. Chase, A.F.; Chase, D.Z.; Awe, J.J.; Weishampel, J.F.; Iannone, G.; Moyes, H.; Yeager, J.; Brown, K.; Shresta, R.L.; Carter, W.E.; et al. Ancient Maya regional settlement and inter-site analysis: The 2013 West-Central Belize LiDAR Survey. Remote Sens. 2014, 6, 8671-8695. [CrossRef]

115. Chase, A.Z.S.; Chase, D.Z.; Chase, A.F. LiDAR for archaeological research and the study of historical landscapes. In Sensing the Past; Geotechnologies and the Environment; Masini, N., Soldovieri, F., Eds.; Springer: Berlin/Heidelberg, Germany, 2017; Volume 16, pp. 89-100.

116. Evans, D. Airborne laser scanning as a method for exploring long-term socio-ecological dynamics in Cambodia. J. Archaeol. Sci. 2016, 74, 164-175. [CrossRef]

117. Grammer, B.; Draganits, E.; Gretscher, M.; Muss, U. LiDAR-guided archaeological survey of a Mediterranean landscape: Lessons from the Ancient Greek polis of Kolophon (Ionia, Western Anatolia). Archaeol. Prospect. 2017, 24, 311-333. [CrossRef] [PubMed]

118. Hesse, R. The changing picture of archaeological landscapes: Lidar prospection over very Large areas as part of a cultural heritage strategy. In Interpreting Archaeological Topography: 3D Data, Visualisation and Observation; Opitz, R.S., Cowley, D.C., Eds.; Oxbow Books: Oxford, UK, 2013; Volume 5, pp. 171-183.

119. Johnson, K.M.; Ouimet, W.B. An observational and theoretical framework for interpreting the landscape palimpsest through airborne LiDAR. Appl. Geogr. 2018, 91, 32-44. [CrossRef]

120. Ladefoged, T.N.; McCoy, M.D.; Asner, G.P.; Kirch, P.V.; Puleston, C.O.; Chadwick, O.A.; Vitousek, P.M. Agricultural potential and actualized developent in Hawai'i: An airborne LiDAR survey of the leeward Kohala field system (Hawai'i Island). J. Archaeol. Sci. 2011, 38, 3605-3619. [CrossRef]

121. Mlekuž, D. Airborne laser scanning and landscape archaeology. Opusc. Archaeol. 2018, 39, 85-95. [CrossRef]

122. O’Reilly, D.; Evans, D.; Shewan, L. Airborne LiDAR prospection at Lovea, an Iron Age moated settlement in central Cambodia. Antiquity 2017, 91, 947-965. [CrossRef]

123. Rosenswig, R.M.; López-Torrijos, R.; Antonelli, C.E.; Mendelsohn, R.R. Lidar mapping and surface survey of the Izapa state on the tropical piedmont of Chiapas, Mexico. J. Archaeol. Sci. 2013, 40, 1493-1507. [CrossRef]

124. Rosenswig, R.M.; López-Torrijos, R. Lidar reveals the entire kingdom of Izapa during the first millennium BC. Antiquity 2018, 92, 1292-1309. [CrossRef]

125. Werbrouck, I.; Antrop, M.; van Eetvelde, V.; Stal, C.; de Maeyer, P.; Bats, M.; Bourgeois, J.; Court-Picon, M.; Crombé, P.; de Reu, J.; et al. Digital Elevation Model generation for historical landscape analysis based on LiDAR data, a case study in Flanders (Belgium). Expert Syst. Appl. 2011, 38, 8178-8185. [CrossRef]

126. Schmidt, J.; Werther, L.; Zielhofer, C. Shaping pre-modern digital terrain models. The former topography at Charlemagne's canal construction site. PLoS ONE 2018, 13, e0200167. [CrossRef] [PubMed]

127. RisbøL, O. Cultivating the "Wilderness"-How LiDAR can improve archaeological landscape understanding. In Interpreting Archaeological Topography: 3D Data, Visualisation and Observation; Opitz, R.S., Cowley, D.C., Eds.; Oxbow Books: Oxford, UK, 2013; Volume 5, pp. 53-64.

128. Gillings, M.; Mattingly, D.J.; van Dalen, J. (Eds.) Geographical Information Systems and Landscape Archaeology; Archaeology of Mediterranean landscapes; Oxbow: Oxford, UK, 2000; Volume 3.

129. Lock, G. Using Computers in Archaeology: Towards Virtual Pasts; Routledge, Taylor \& Francis Group: London, UK; New York, NY, USA, 2003. 
130. Wheatley, D.; Gillings, M. Spatial Technology and Archaeology: The Archaeological Applications of GIS; Taylor \& Francis Ltd.: London, UK, 2002.

131. Risbøl, O.; Petersen, T.; Jerpåsen, G. Approaching a mortuary monuments landscape using GIS and LiDAR generated 3D models. Int. J. Herit. Digit. Era 2013, 2, 509-525. [CrossRef]

132. Risbøl, O.; Gustavsen, L. LiDAR from drones employed for mapping archaeology-Potential, benefits and challenges. Archaeol. Prospect. 2018, 25, 329-338. [CrossRef]

133. Häkkilä, H.; (email to Seitsonen, Helsinki, Finland). Personal Communication, 2019.

134. Lavento, M.; (email to Seitsonen, Helsinki, Finland). Personal Communication, 2019.

135. Roiha, J.; (email to Seitsonen, Helsinki, Finland). Personal Communication, 2020.

136. Risbøl, O.; Berge, R.; Grav Ellingsen, E. Kunnskapsbygging i fellesskap. LiDAR-basert kartlegging av kulturminner i utmarka i Klæbu. Klæbu Historielag. Årsskrift 2018, 31-33.

137. Seitsonen, O. Lidar-kaukokartoitus arkeologien apuna. Positio 2019, 4, 19-20.

138. Mikkonen, K. Parakkeja ja Piikkilankaa; Lapin maakuntamuseo: Rovaniemi, Finland, 2016.

139. Sillanpää, E.; Rikkinen, A. Projekti Sturmbock. Loppuraportti; Survey report; Järämä: Enontekiö, Finland, 2019.

140. Aarmo, B. Metallsøking; Museumsforlaget: Trondheim, Norway, 2019.

141. Seitsonen, O. Crowdsourcing cultural heritage: Public participation and conflict legacy in Finland. J. Community Archaeol. Herit. 2017, 4, 115-130. [CrossRef]

142. MacGyver 2018. 3D Rinnevarjokartta. Available online: https://www.aarremaanalla.com/foorumi/viewtopic. php? $\mathrm{f}=10 \& \mathrm{t}=23689$ (accessed on 1 April 2019).

143. Sittler, B. Revealing historical landscapes by using airborne laser scanning. A 3-D model of ridge and furrow in forests near Rastatt (Germany). In Laser-Scanners for Forest and Landscape Assessment, Proceedings of the ISPRS Working Group 8/2, Freiburg, Germany, 3-6 October 2004; International Archives of Photogrammetry, Remote Sensing and Spatial Information Sciences: Freiburg, Germany, 2004; Volume 36, Part 8/W2; pp. $258-261$.

144. Sittler, B.; Schellberg, S.; Siepman-Schinker, D.; Weinacker, H. Airborne laserscanning to generate 3D models of microrelief features for the purposes of forest ecological and archaeological surveys. In 3D Remote Sensing in Forestry (Conference Proceedings), Vienna; Department of Spatial, Landscape and Infrastructure Sciences, University of Natural Resources and Applied Life Sciences: Vienna, Austria, 2006.

145. Doneus, M.; Briese, C. Digital terrain modelling for archaeological interpretation within forested areas using full-waveform laserscanning. In The 7th International Symposium on Virtual Reality, Archaeology and Cultural Heritage VAST; GCH: Aire-La-Ville, Switzerland, 2006; pp. 155-162.

146. Doneus, M.; Briese, C.; Fera, M.; Fornwagner, U.; Griebl, M.; Janner, M.; Zingerle, M.C. Documentation and analysis of archaeological sites using aerial reconnaissance and airborne laser scanning. In Proceedings of the XXIth International CIPA Symposium, Athens, Greece, 1-6 October 2007; XXXVI-5/C53, XXXVI-5/C53. pp. 275-280.

147. Bernardini, F.; Sgambati, A.; Montagnari Kokelj, M.; Zaccaria, C.; Micheli, R.; Fragiacomo, A.; Tiussi, C.; Dreossi, D.; Tuniz, C.; De Min, A. Airborne LiDAR application to karstic areas: The example of Trieste province (north-eastern Italy) from prehistoric sites to Roman forts. J. Archaeol. Sci. 2013, 40, 2152-2160. [CrossRef]

148. Banaszek, L. The Past amidst the Woods. The Post-Medieval Landscape of Polanów; Ad Rem: Poznań, Poland, 2019; ISBN 978-83-916342-6-4.

149. Bofinger, J.; Hesse, R. As far as the laser can reach...Laminar analysis of LiDAR detected structures as a powerful instrument for archaeological heritage management in Baden-Württemberg, Germany. In Remote Sensing for Archaeological Heritage Management; Cowley, D.C., Ed.; EAC Occasional Paper No. 5; Europae Archaeologia Consilium (EAC): Brussels, Belgium, 2011; pp. 161-171.

150. Challis, K.; Kokalj, Z.; Kincey, M.; Moscrop, D. Airborne lidar and historic environment records. Antiquity 2008, 82, 1055-1064. [CrossRef]

151. Bennett, R.; Welham, K.; Hill, R.A.; Ford, A. A comparison of visualization techniques for models created from airborne laser scanned data. Archaeol. Prospect. 2012, 19, 41-48. [CrossRef]

152. Hare, T.; Masson, M.; Russell, B. High-Density LiDAR mapping of the ancient city of Mayapán. Remote Sens. 2014, 6, 9064-9085. [CrossRef]

153. Schneider, A.; Takla, M.; Nicolay, A.; Raab, A.; Raab, T. A template-matching approach combining morphometric variables for automated mapping of charcoal kiln sites. Archaeol. Prospect. 2014, 22, 45-62. [CrossRef] 
154. Bennett, R.; Cowley, D.C.; De Laet, V. The data explosion: Tackling the taboo of automatic feature recognition in airborne survey data. Antiquity 2014, 88, 896-905. [CrossRef]

155. Vletter, W.F. A workflow for (semi) automatic extraction of roads and paths in forested areas from Airborne Laser Scan data. AARGNews 2015, 50, 33-40.

156. Kincey, M.; Challis, K. Monitoring fragile upland landscapes: The application of airborne lidar. J. Nat. Conserv. 2010, 18, 126-134. [CrossRef]

157. Kincey, M.; Batty, L.; Chapman, H.; Gearey, B.; Ainsworth, S.; Challis, K. Assessing the changing condition of industrial archaeological remains on Alston Moor, UK, using multisensor remote sensing. J. Archaeol. Sci. 2014, 45, 36-51. [CrossRef]

158. Shaw, R.; Corns, A. High resolution LiDAR specifically for archaeology: Are we fully exploiting this valuable resource? In Remote Sensing for Archaeological Heritage Management; Cowley, D.C., Ed.; EAC Occasional Paper No. 5; Europae Archaeologia Consilium (EAC): Brussels, Belgium, 2011; pp. 77-86.

159. Doneus, M.; Briese, C.; Kühtreiber, T. Flugzeuggetragenes laserscanning als werkzeug der archäologischen kulturlandschaftsforschung. Archäologisches Korresp. 2008, 38, 137-156.

160. Crutchley, S. Shedding light on the past: Using airborne LIDAR to understand ancient landscapes. In Geoinformation Technologies for Geocultural Landscapes: European Perspectives; Bender, O., Evelpidou, N., Krek, A., Vassilopoulos, A., Eds.; CRC Press, Taylor \& Francis Group: London, UK; New York, NY, USA; Leiden, The Netherlands, 2009; pp. 87-103.

161. Chase, A.F.; Chase, D.Z.; Weishampel, J.F.; Brake, J.B.; Shresta, R.L.; Clint Slatton, K.; Awe, J.; Carter, W. Airborne LiDAR, archaeology, and the ancient Maya landscape at Caracol, Belize. J. Archaeol. Sci. 2011, 38, 387-398. [CrossRef]

162. Opitz, R.; Nuninger, L.; Fruchart, C. Thinking topographically about the landscape around besancon (Doubs, France). In Landscape Archaeology Between Art and Science: From a Multi- to an Interdisciplinary Approach; Kluiving, S.J., Guttmann-Bond, E.B., Eds.; Amsterdam University Press: Amsterdam, The Netherlands, 2012; pp. 395-412.

163. McNeary, R. Applications of airborne LiDAR for cultural heritage management initiatives in Northern Ireland. In A Sense of the Past. Studies in Current Archaeological Applications of Remote Sensing and Non-Invasive Prospection Methods; Kamermans, H., Gojda, M., Posluschny, A.G., Eds.; BAR International Series 2588; British Archaeological Reports: Oxford, UK, 2014; pp. 67-82.

164. Randall, A.R. LiDAR-aided reconnaissance and reconstruction of lost landscapes: An example of freshwater shell mounds (ca. 7500-500 CAL B.P.) in northeastern Florida. J. Field Archaeol. 2014, 39, 162-179. [CrossRef]

165. Challis, K.; Carey, C.; Kincey, M.; Howard, A.J. Airborne lidar intensity and geoarchaeological prospection in river valley floors. Archaeol. Prospect. 2011, 18,1-13. [CrossRef]

166. Challis, K.; Howard, A.J.; Kincey, M.; Moscrop, D.; Carey, C.J.; Hill, T.; Smith, D.N.; Gearey, B.R.; Thompson, A. Using airborne lidar intensity to predict the organic preservation of waterlogged deposits. In From Space to Place: 2nd International Conference on Remote Sensing in Archaeology; Campana, S., Forte, M., Eds.; British Archaeological Review; Archaeopress: Oxford, UK, 2006; Volume 1568, pp. 93-98.

167. Challis, K.; Howard, A. The role of lidar intensity data in interpreting environmental and cultural archaeological landscapes. In Interpreting Archaeological Topography: 3D Data, Visualisation and Observation; Opitz, R.S., Cowley, D.C., Eds.; Oxbow Books: Oxford, UK, 2013; Volume 5, pp. 161-170.

168. Doneus, M.; Doneus, N.; Briese, C.; Pregesbauer, M. Airborne laser bathymetry-Detecting and recording submerged archaeological sites from the air. J. Archaeol. Sci. 2013, 40, 2136-2151. [CrossRef]

169. Shih, P.T.Y.; Chen, Y.H.; Chen, J.C. Historic shipwreck study in Dongsha Atoll with bathymetric LiDAR. Archaeol. Prospect. 2014, 21, 139-146. [CrossRef]

170. Menna, F.; Agrafiotis, P.; Georgopoulos, A. State of the art and applications in archaeological underwater 3D recording and mapping. J. Cult. Herit. 2018, 33, 231-248. [CrossRef]

171. Metternich, G.; Hurni, L.; Gogu, R. Remote Sensing of landslides: An analysis of the potential contribution to geo-spatial systems for hazard assessment in mountainous environments. Remote Sens. Environ. 2005, 98, 284-303. [CrossRef]

172. Limber, P.W.; List, J.H.; Warren, J.D. Management applications of LIDAR-derived mean high-water shorelines in North Carolina. In Proceedings of the Coastal Zone 07, Portland, OR, USA, 22-26 July 2007.

173. Robertson, W.; Whitman, D.; Zhang, K.; Leatherman, S.P. Mapping shoreline position using airborne laser altimetry. J. Costal Res. 2004, 20, 884-892. [CrossRef] 
174. Stockdon, H.; Sallenger, A.; Holman, R.; List, J. Estimation of shoreline position and change using airborne topographic lidar data. J. Costal Res. 2002, 18, 502-513.

175. Duckers, G.L. Bridging the "Geospatial Divide". Archaeology: Community Based Interpretation of LIDAR Data. Internet Archaeol. 2013, 35. [CrossRef]

176. Thorne, A. 2016: Out in the field. In Secrets of the High Woods. Revealing Hidden Landscapes; Manley, J., Ed.; South Downs National Park Authority: London, UK, 2016; Chapter 7; pp. 23-25, ISBN 978-1-5272-0302-0.

177. Khan, S.; Aragão, L.; Iriarte, J. A UAV-lidar system to map amazonian rainforest and its ancient landscape transformations. Int. J. Remote Sens. 2017, 38, 2313-2330. [CrossRef]

178. VanValkenburgh, P.; Cushman, K.C.; Castillo Butters, J.L.; Vega, C.R.; Roberts, C.B.; Kepler, C.; Kellner, J. Lasers without lost cities: Using drone lidar to capture architectural complexity at Kuelap, Amazonas, Peru. J. Field Archaeol. 2020, 45, S75-S88. [CrossRef]

179. Millard, K.; Bruke, C.; Stiff, D.; Redden, A. Detection of a low-relief 18thcentury British siege trench using LiDAR vegetation penetration capabilities at Fort Beauséjour-Fort Cumberland national historic site, Canada. Geoarchaeology Int. J. 2009, 24, 576-587. [CrossRef]

180. Maio, C.V.; Tenenbaum, D.E.; Brown, C.J.; Mastone, V.T.; Gontz, A.M. Application of geographic information technologies to historical landscape reconstruction and military terrain analysis of an American Revolution Battlefield: Preservation potential of historic lands in urbanized settings, Boston, Massachusetts, USA. J. Cult. Herit. 2013, 14, 317-331. [CrossRef]

(C) 2020 by the authors. Licensee MDPI, Basel, Switzerland. This article is an open access article distributed under the terms and conditions of the Creative Commons Attribution (CC BY) license (http://creativecommons.org/licenses/by/4.0/). 